\title{
Noncoding RNAs implication in cardiovascular diseases in the COVID-19 era
}

\author{
S. Greco ${ }^{1 \dagger}$, A. Madè $^{1 \dagger}$, C. Gaetano ${ }^{2}$, Y. Devaux ${ }^{3}$, C. Emanueli ${ }^{4}$ and F. Martelli ${ }^{1 *}$ (B)
}

\begin{abstract}
COronaVIrus Disease 19 (COVID-19) is caused by the infection of the Severe Acute Respiratory Syndrome CoronaVirus 2 (SARS-CoV-2). Although the main clinical manifestations of COVID-19 are respiratory, many patients also display acute myocardial injury and chronic damage to the cardiovascular system. Understanding both direct and indirect damage caused to the heart and the vascular system by SARS-CoV-2 infection is necessary to identify optimal clinical care strategies. The homeostasis of the cardiovascular system requires a tight regulation of the gene expression, which is controlled by multiple types of RNA molecules, including RNA encoding proteins (messenger RNAs) (mRNAs) and those lacking protein-coding potential, the noncoding-RNAs. In the last few years, dysregulation of noncoding-RNAs has emerged as a crucial component in the pathophysiology of virtually all cardiovascular diseases. Here we will discuss the potential role of noncoding RNAs in COVID-19 disease mechanisms and their possible use as biomarkers of clinical use.
\end{abstract}

Keywords: COVID-19, SARS-CoV-2, Cardiovascular disease, Noncoding RNAs, Transcriptomics

\section{Introduction}

The novel human Severe Acute Respiratory Syndrome CoronaVirus 2 (SARS-CoV-2), isolated on 7th January 2020, has been identified as the cause of acute respiratory distress syndrome (ARDS) cases of unknown etiology detected in Wuhan City, Hubei province of China and then indicated as Coronavirus Disease 2019 (COVID-19) [1]. Because of the rapid global spread of the COVID-19, on 11th March 2020, the Director-General of the World Health Organization (WHO) defined the disease as a pandemic [2] and up to October 27th 2020, there have been more than 43 million confirmed cases and more than 1 million deaths worldwide [3].

The main clinical manifestations of COVID-19 are respiratory. However, many patients also display a severe involvement of the cardiovascular system [4-9]. Thus,

\footnotetext{
*Correspondence: fabio.martelli@grupposandonato.it

${ }^{\dagger} \mathrm{S}$. Greco and A. Madè contributed equally

1 Molecular Cardiology Laboratory, IRCCS Policlinico San Donato, San Donato Milanese, 20097 Milan, Italy

Full list of author information is available at the end of the article
}

it is of paramount importance to understand the direct and indirect damage caused to the cardiovascular system by SARS-CoV-2 infection, as well as the underpinning pathogenetic mechanisms.

Here we will review the importance of transcriptomics techniques in our understanding of human coronavirus disease mechanisms in the cardiovascular system and for the identification of biomarkers of potential clinical use. Specifically, we will focus on noncoding RNAs (ncRNAs), an emerging class of regulatory RNAs [10]. Given their fundamental role in gene expression regulation, we propose ncRNAs as promising candidates for understanding the consequences of SARS-CoV-2 infection on the cardiovascular system.

\section{Noncoding RNAs}

Analysis of the human genome has shown that less than $2 \%$ is transcribed into protein-coding RNAs (mRNAs), while almost $60 \%$ is transcribed into RNAs lacking protein-coding potential (ncRNAs) [11, 12].

Based on their transcript size, ncRNAs can be classified into two groups using 200 nucleotides as length

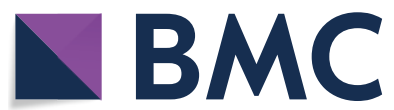

(c) The Author(s) 2020. This article is licensed under a Creative Commons Attribution 4.0 International License, which permits use, sharing, adaptation, distribution and reproduction in any medium or format, as long as you give appropriate credit to the original author(s) and the source, provide a link to the Creative Commons licence, and indicate if changes were made. The images or other third party material in this article are included in the article's Creative Commons licence, unless indicated otherwise in a credit line to the material. If material is not included in the article's Creative Commons licence and your intended use is not permitted by statutory regulation or exceeds the permitted use, you will need to obtain permission directly from the copyright holder. To view a copy of this licence, visit http://creativeco mmons.org/licenses/by/4.0/. The Creative Commons Public Domain Dedication waiver (http://creativecommons.org/publicdomain/ zero/1.0/) applies to the data made available in this article, unless otherwise stated in a credit line to the data. 
threshold: small noncoding RNAs (small ncRNAs) and long noncoding RNAs (lncRNAs). The most studied small ncRNAs are microRNAs (miRNAs) and long ncRNAs, which include also circular RNAs (circRNAs) [11, 13].

MicroRNAs (miRNAs) are short noncoding RNAs (18-25 nucleotides) that modulate gene expression by sequence-specific recognition of their target transcripts. Most miRNA genes are transcribed by RNA polymerase II from intergenic, intronic or polycistronic loci forming an intermediate hairpin of 60-70 nucleotide, named "precursor miRNA" (pre-miRNA) [14]. The pre-miRNA is then transported out of the nucleus and cleaved by the cytoplasmic RNase III Dicer into a short miRNA duplex $[15,16]$. One strand of this duplex binds to the Argonaute (AGO) protein forming the RNA-induced silencing complex (RISC), which can recognize the target mRNA by sequence complementarity $[17,18]$. This binding leads to the degradation and/or translational inhibition of the target mRNAs. Each miRNA can have hundreds of RNA targets and also a single mRNA may have several miRNA recognition sequences, generating complex regulatory networks [19].

LncRNAs are ncRNAs regulating the transcription and translation of protein-coding gene expression [20-23]. They have some similarities with coding genes, such as the presence of epigenetic marks, introns and the existence of splice variants, and the transcription driven by promoter elements. Moreover, they can be either polyadenylated or non-polyadenylated [24]. They may originate from either the sense or antisense DNA strand, can overlap coding genes entirely or partly. They can be divided in sense, antisense, intronic, intergenic, and bidirectional lncRNAs, enhancer-associated RNAs (eRNAs), and promoter associated long RNAs (PALRs) [25]. Finally, there are circRNAs, that are circularized RNAs generated by back-splicing events of pre-mRNAs [26].

LncRNAs can function as epigenetic regulators, can regulate the transcription rate by assembling transcriptional activators and repressors [27]. Some nuclear lncRNAs have been implicated in maintaining nuclear structures, including interchromatin granules, nuclear speckles and paraspeckles [22]. LncRNAs can also regulate the gene expression by binding to mRNAs and modulating their translation and/or stability [28, 29]. Despite their generally low-abundance, some lncRNAs can accumulate because they high stability and, by sequestering miRNAs, can function as competing endogenous RNAs (ceRNAs) [30, 31].

\section{Coronavirus biology}

Sars-CoV-2 belongs to the Beta-coronavirus genus of the Coronaviridae family; like the other members of the family, Sars-CoV-2 is enveloped and its genome is a single-stranded positive-sense RNA of around $30 \mathrm{~kb}$ [32]. Coronaviruses genome encodes for nonstructural proteins and for four structural proteins: spike (S), envelope $(\mathrm{E})$, membrane $(\mathrm{M})$ and nucleocapsid $(\mathrm{N})$ proteins (Fig. 1) [33]. The S protein can recognize the receptor of the host cell and is responsible for cell membrane fusion [34], the N protein interacts with the viral RNA to assemble the ribonucleoprotein [35], the E protein is necessary for virion assembly [36] and the $\mathrm{M}$ protein has a pivotal role in virus assembly [37].

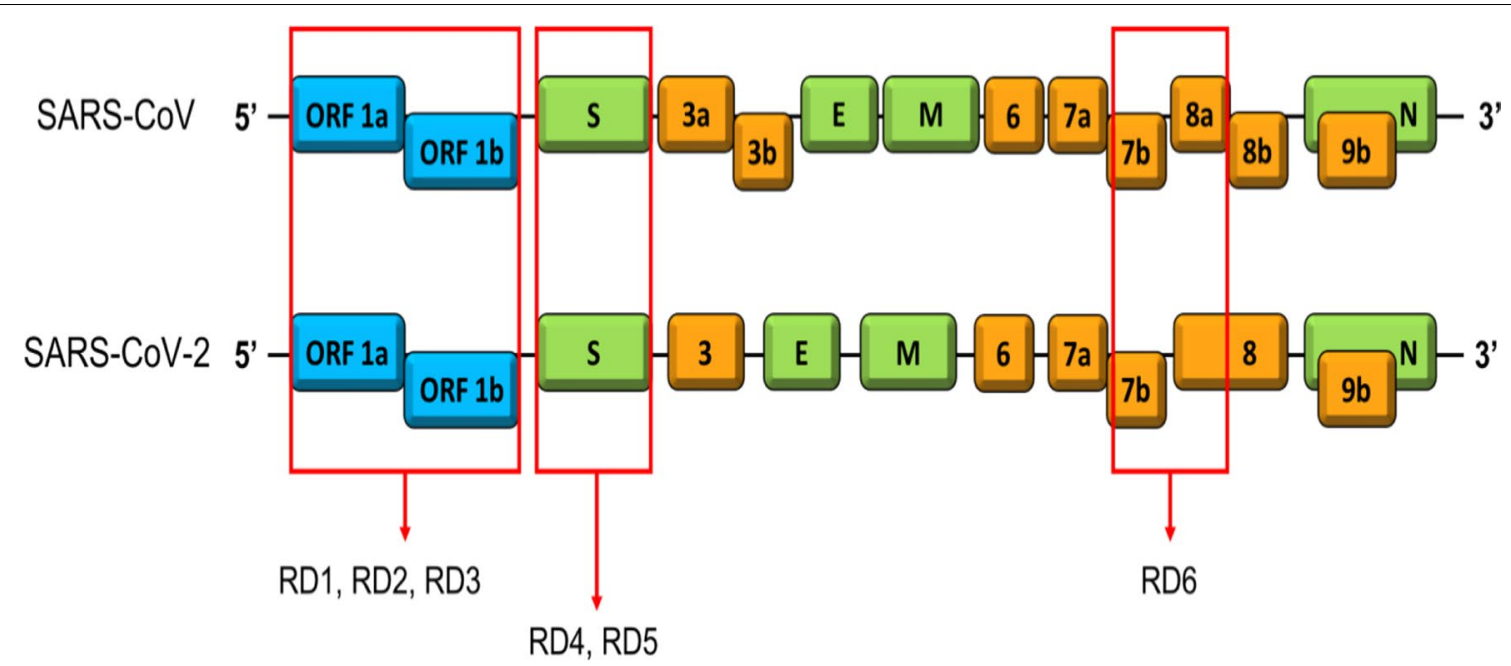

Fig. 1 Differences between genome of SARS-CoV and SARS-CoV-2. The six regions of difference (RD) are indicated by red rectangles 
All the members of the Coronaviridae family seem to have the same replication mechanism: the genomic RNA represents the template used to translate two partly overlapping open reading frames in two polyproteins, which encode the nonstructural proteins necessary to the replication-transcription complexes assembly in association with cytoplasmic membranes [32, 38].

Coronaviruses can infect many animal species, causing different symptoms, such as respiratory and intestinal diseases [39, 40]. Among human coronaviruses, severe acute respiratory syndrome-coronavirus (SARS$\mathrm{CoV}$ ) and Middle East respiratory syndrome-coronavirus (MERS-CoV) are the best studied, due to the epidemics that originated in 2002 and 2012, respectively [39].

Virology and genetic studies indicate that human coronaviruses have a reservoir in nature not corresponding with the intermediary host species, which is responsible for dissemination to humans [39-41]. Since SARS-CoV-2 genome is more than $96 \%$ identical to a bat coronavirus, it is very likely that bats may have been the initial zoonotic host [42]. However, the intermediary species is unknown. The most common human-human transmission is through respiratory droplets generated by sneezing and coughing [43].

Genetic sequence analysis revealed that Sars-CoV-2 has $79.0 \%$ nucleotide identity to SARS-CoV and 51.8\% identity to MERS-CoV [44, 45]. Comparing Sars-CoV-2 and SARS-CoV genomes, six regions of difference have been recognized (Fig. 1). Based on proteomic comparison, SARS-CoV-2 proteins are highly homologous (about $95 \%-100 \%)$ to the SARS-CoV virus proteins [45]. The similarity of SARS-CoV and SARS-CoV-2 viruses is also confirmed by the fact that they both use angiotensinconverting enzyme 2 (ACE2) as cellular receptor, via the receptor-binding domain of surface spike glycoprotein $\mathrm{S}$ [46-48].

For their similar structural and pathogenicity features, the better studied SARS-CoV and MERS-CoV constitute important models when developing hypothesis for SARS-CoV-2 disease mechanisms.

\section{COVID-19 implication of the cardiovascular system}

Patients with pre-existing cardiovascular diseases (CVDs) have a higher risk of severe disease and death upon SARS-CoV-2 infection [4-6, 8]. It is plausible that COVID-19 can affect the cardiovascular system at various levels. Indeed, ACE2 is expressed by a multitude of cell types, including cardiac and vascular cells [49], which may represent direct targets. Accordingly, SARS$\mathrm{CoV}-2$ infection has been associated with multiple direct and indirect cardiovascular complications including arrhythmias as well as myocardial injury due to hypoxia, microvascular thrombosis and systemic cytokine release syndrome ("cytokine storm") $[8,50]$. Indeed, the immune response is crucial for infection resolution, but this response can also result in immunopathogenesis. During the disease course, SARS-CoV viral loads were observed to decrease while disease severity increased, suggesting that immunopathogenesis may contribute to ARDS [51] and may be an important cause of cardiovascular damage (Fig. 2).

Moreover, antiviral therapies under investigation for COVID-19 may damage the heart and have other cardiovascular side effects, such as arrhythmias and repolarization abnormalities [52].

\section{SARS-CoV2 and its receptor ACE2}

ACE2 is an integral membrane carboxymonopeptidase that has been identified as a functional receptor for coronaviruses, including SARS-CoV and SARS-CoV-2 [48, 53-55]. In this process, it is crucial the $\mathrm{S}$-protein priming by the Transmembrane Serine Protease 2 TMPRSS2 [54].

ACE2 is expressed in alveolar epithelial cells, in line with the respiratory symptoms of COVID-19, but also in other epithelial and non-epithelial cells, in the kidneys and the gut. With relevance to the potential cardiac impact of COVID-19, ACE2 is also expressed by cardiomyocytes, fibroblasts, pericytes, macrophages and the epicardial fat [49, 56-58].

ACE2 is an important member of the renin angiotensin system [54]. As shown in Fig. 2, ACE2 activity is necessary to generate Angiotensin 1-7, which, via the activation of the G protein-coupled MAS receptor, leads to vasodilatory, anti-hypertrophic, and anti-fibrotic effects. This represents an important mechanism to compensate the negative cardiovascular action of an excessive Angiotensin II stimulation on the Angiotensin II Type 1 Receptor (AT1R) (Fig. 3).

In keeping with an important role of ACE2 in the heart, ACE2 knockout mice display impaired cardiac contractility and the upregulation of the hypoxia-associated gene program [58]. In both the mouse model of acute myocardial infarction (AMI) and in idiopathic and ischemic heart failure (HF) patients, increased expression of ACE2 protein and mRNA has been observed [59, 60].

Moreover, ACE2 is a transmembrane protein, whose catalytic domain is located at the extracellular side of the cell and it can be released into the blood after cleavage by ADAM17 (also named TACE). Previous studies have reported increases in circulating ACE2, possibly due to augmented ACE2 shedding, to be associated with cardiovascular risk factors, such as advanced age and diabetes mellitus [61], which are also risk factors for COVID-19 $[8,50]$.

Given ACE2 expression in the heart, it is conceivable that the SARS-CoVs virus can have a direct effect 


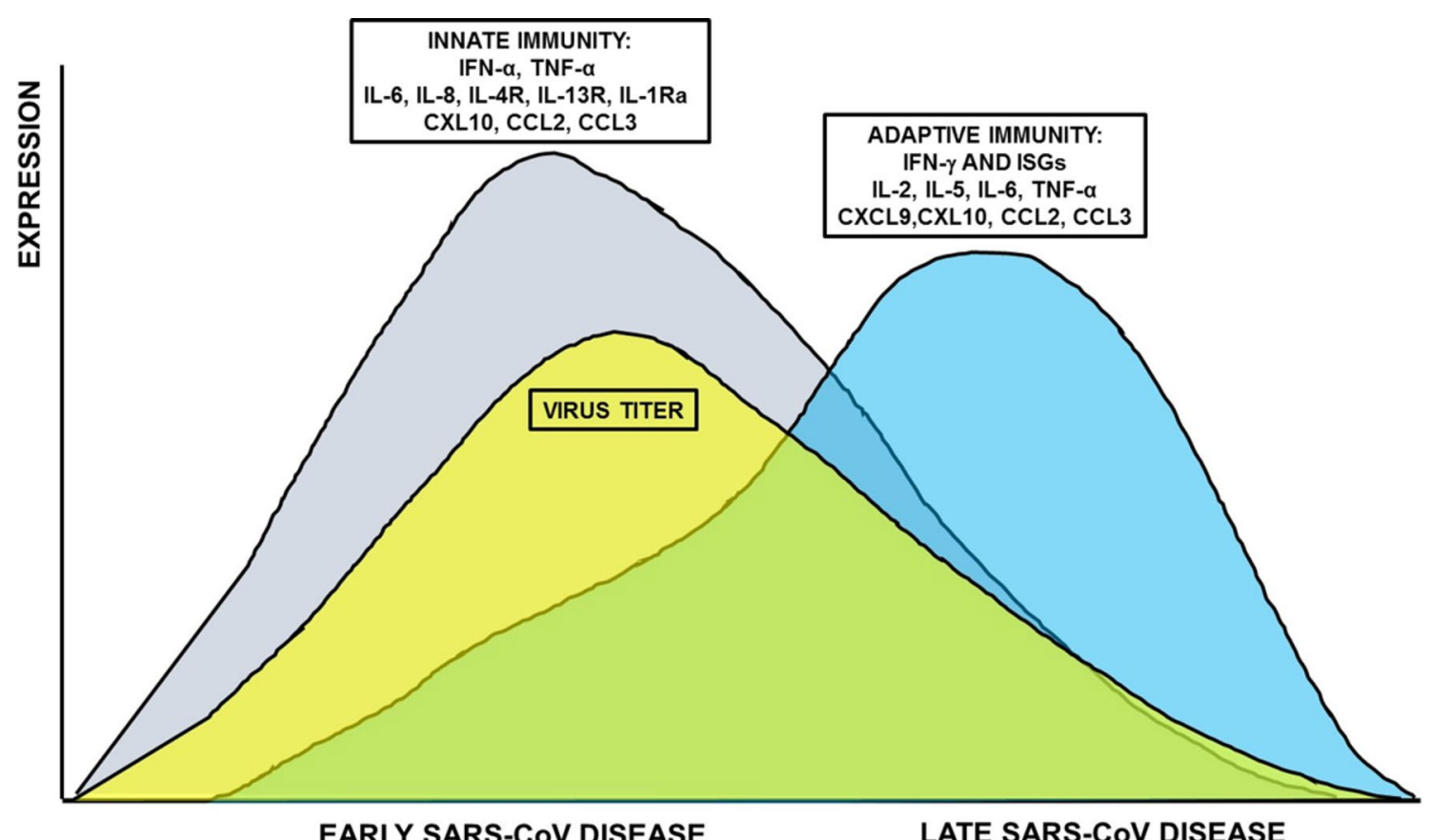

Fig. 2 Time course of host responses to SARS-CoV infection in humans. A biphasic expression of inflammatory mediators is associated with the early disease, where the cellular infiltration into the lungs, peaks with the higher viral titer and the late disease that corresponds to viral clearance in non-complicated ARDS. The switch from innate to adaptive immune response is important for fighting ARDS

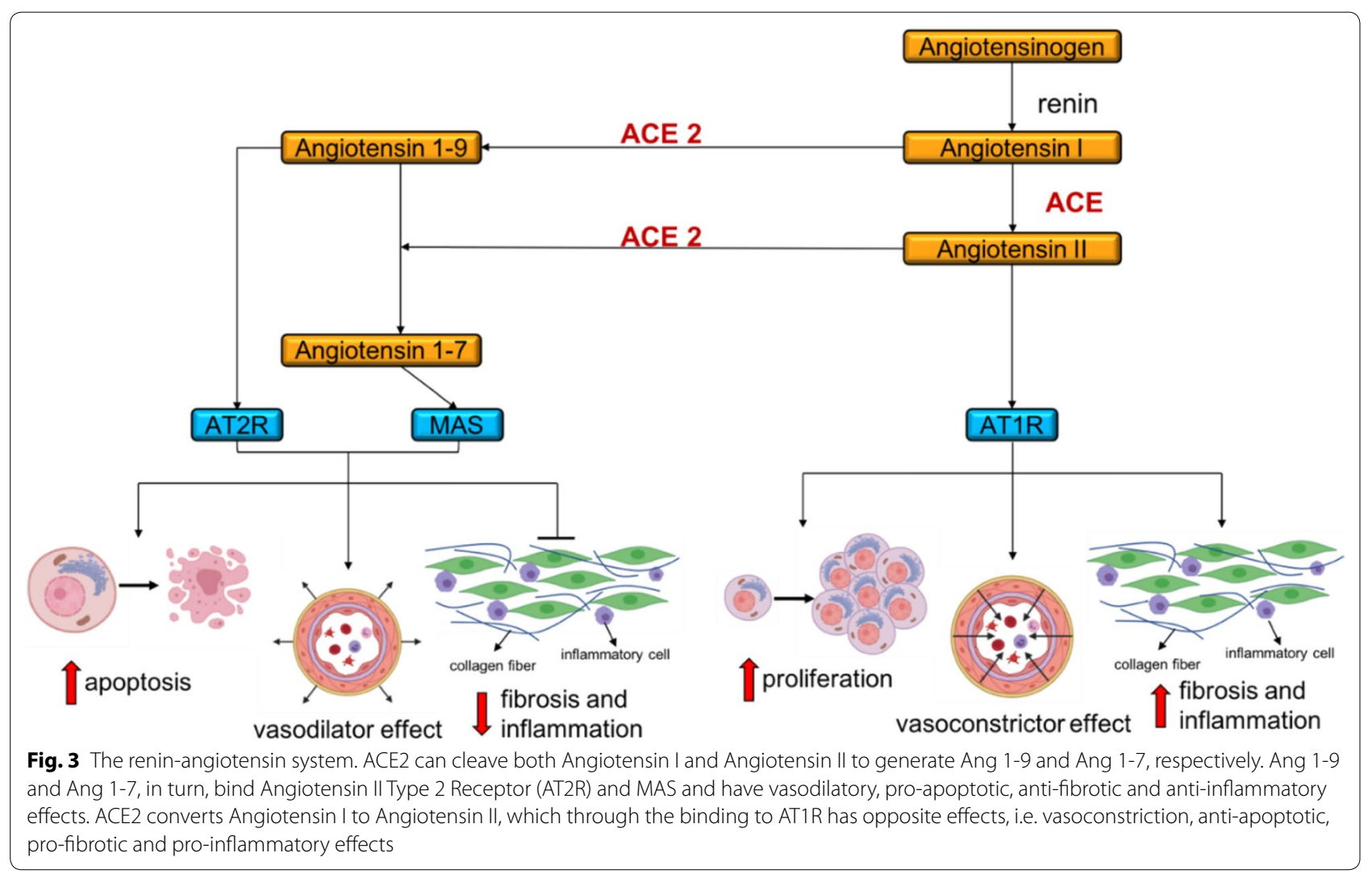


on cardiac function. Accordingly, in several SARS$\mathrm{CoV}$ patients, viral RNA was detected not only in the lungs, but also in the myocardium [62, 63]. Increased ACE2 expression in cardiovascular patients [59, 60] may increase their susceptibility to SARS-CoVs infection. However, in the heart of both SARS-CoV infected mice and of SARS patients, decreased ACE2-levels were observed [64], suggesting a complex virus/receptor dynamic that needs to be elucidated.

Further complicating the scenario, ACE2 levels can also be increased by inhibitors of the renin angiotensin system [65]. However, while the impact of these drugs on COVID-19 is still largely unknown, a retrospective study did not identify inhibitors of the renin angiotensin system as independent predictors of poor outcome $[66,67]$.

\section{Acute cardiac injury}

Different studies found that the values of cardiac Troponins were increased in COVID-19 patients with more severe disease $[4,5,68-70]$, indicating an association of SARS-CoV-2 with myocardial damage. Indeed, in a study surveying 187 COVID-19 hospitalized patients [9], myocardial injury identified by increased Troponin $\mathrm{T}$ and $\mathrm{N}$-terminal Pro Brain Natriuretic Peptide (NT-pro-BNP) levels was significantly associated with death, while the prognosis of patients with underlying CVDs, but without myocardial injury, was less severe. Moreover, cardiac injury was associated with cardiac dysfunction and arrhythmias.

Accordingly, there are several studies reporting a direct effect on heart function of coronaviruses with a pathogenicity similar to that of SARS-CoV-2. In a rabbit model of coronavirus infection, viral-cardiomyopathy and progression into dilated cardiomyopathy (DCM) have been described [71]. Moreover, MERS-CoV infection has been associated with acute myocarditis and HF [72]. Interestingly, in the hearts of both SARS-CoV infected mice and SARS patients, macrophage infiltration with evidence of myocardial damage was observed [64]. A similar pattern with low-grade myocardial inflammation and viral particles in the heart has been reported in one COVID-19 case [73]. Cardiomyocytes showed non-specific features such as focal myofibrillar lysis, and lipid droplets, but no viral particles were observed in myocytes and endothelia, suggesting infected macrophage migration from the lung or during a viraemic phase. Other myocarditis single cases in which endomyocardial biopsy was performed scored negative for SARS-CoV-2 genome presence [74, 75]. Thus, further studies with higher numerosity are definitely needed to ascertain the nature of COVID-19 myocarditis.

Li et al. [76] reported in SARS patients an impairment in left ventricular performance during the acute phase, but reversible on clinical recovery. This impairment was more severe in critically ill patients and elevated lactate dehydrogenase levels, reflecting the severity of tissue damage, were associated with decreased ejection fraction [76].

While the expression of ACE2 is well known in heart, it is controversial the expression of TMPRSS2 [77]. These data draw the attention on the mechanism by which the virus could enter in the cardiomyocytes, and on the existence of secondary effects related to hypoxia and systemic inflammation during complicated COVID-19 courses. Indeed, the finding of a more prominent immune reaction in patients with more critical illness, and the association of cytokines as pro-inflammatory mediators in HF, support the hypothesis that the heart function impairment may be due to the cytokine storm in response to SARS infection [76, 78]. Likewise, also in COVID-19 patients, a cytokine storm triggered by the SARS-CoV2 infection may result in damage to myocardial cells.

This strong inflammatory response may also confer risk for atherosclerotic plaque rupture in coronary artery disease patients, increasing the risk of acute coronary syndrome in more severely affected COVID-19 patients, akin to what has been observed in influenza viral illness [79].

Also important in elevating the risk of cardiac injury is hypoxemia caused by respiratory dysfunction, higher risk of capillary embolism [80] and the increased metabolic demands. Moreover, many antiviral drugs can cause cardiac damage [81], further complicating the clinical situation.

\section{Cardiac arrhythmia}

In hospitalized COVID-19 patients, cardiac arrhythmia was present in more than $15 \%$ of the patients and was far more common in those presenting serious symptoms and requiring intensive care $[5,9]$. While myocarditis should be considered, high prevalence of arrhythmia might be also attributable to hypoxia, cytokine storm syndrome and metabolic disorder in the setting of viral infection, possibly in the presence of prior CVDs.

Indeed, there are several possible pathophysiological causes of arrhythmias such as: 1) the direct injury to cardiomyocytes that alters the membrane electrical conduction, 2) massive edema, 3) ischemia originating from microvascular disease following the infection, 4) re-entrant arrhythmias caused by myocardial fibrosis or scars and 5) proinflammatory cytokines storm. The first three events could occur in the acute setting, while the fourth and fifth are associated with chronic or healed myocarditis. Moreover, the proinflammatory cytokines storm (e.g., IL-6) might cause alteration in the 
desmosomal proteins of the cardiomyocyte membrane that could be arrhythmogenic $[75,82]$.

\section{Previously existing cardio-metabolic diseases}

There is increasing evidence that patients with CVDs and/or diabetes mellitus are more likely to develop severe symptoms when affected by COVID-19 [4-6, 83, 84]. Among COVID-19 patients with severe symptoms, many had hypertension, heart disease and arrhythmia. Acute coronary syndrome seems to have a particularly poor prognosis in COVID-19 patients. Indeed, upon SARSCoV-2 infection, cardiac insufficiency is more likely to occur in these patients where cardiac function is already compromised by myocardial ischemia [4-6, 83, 84].

Moreover, SARS-CoV infection leads to long term disorders of lipid and glucose metabolism [85]. Considering the similarities between SARS-CoV and SARS$\mathrm{CoV}-2$, this novel virus might also inflict a similar chronic damage.

\section{Noncoding RNAs in cardiovascular diseases}

Transcriptomics has been extensively used to understand CVD pathogenesis, to identify coding and ncRNAs with a potential as therapeutic targets and clinically useful biomarkers. These studies have been extensively reviewed elsewhere [10, 86-89]. Here we will only give few examples that may be paradigmatic also in the investigation of the cardiovascular implications of COVID-19.

Transcriptomics first focused on mRNAs expressed in the heart, identifying transcripts encoding mostly contractile sarcomeric proteins, cytoskeletal proteins, ion channels, intracellular signal transducers, including apoptosis and cell proliferation genes, and proteins maintaining the redox state of the myocardium [90, 91].

Transcriptomic profiling identified several miRNAs deregulated in left ventricles (LV) of both dilated (DCM) and ischemic cardiomyopathy (ICM) patients [92]. Additional studies allowed identification also of signatures specific to particular cardiomyopathies, such as DCM in patients with reduced catecholamine sensitivity [93], DCM in patients with a reverse-remodeling response following $\beta$-blocker treatment [94] and ICM in patients affected by type 2 diabetes mellitus [95].

MiRNA expression is also dysregulated in viral myocarditis [96-98]. In particular, miR-155-5p is one of the miRNAs consistently modulated in both human and mouse viral myocarditis, contributing to myocardial damage through the modulation of monocyte-macrophages cardiac infiltration and T lymphocyte activation [98].

Genome-wide analyses of LV samples of HF patients identified a subset of lncRNAs significantly deregulated compared with healthy controls; despite the limited evolutionary conservation of lncRNAs, many of these findings were also confirmed in relevant mouse models of disease [86, 99-103].

Particularly relevant are circRNAs originating from the multi-exon gene Titin, that are dysregulated in both dilated and hypertrophic cardiomyopathies, and are regulated by the splicing factor RNA binding motif protein 20 (RBM20) [104].

Of great translational relevance is the fact that ncRNAs are released into the blood where they are sufficiently stable to be readily measured with common laboratory techniques, such as $\mathrm{qPCR}$, and that their concentration levels can differentiate diseased patients from healthy subjects. In addition, their measurement requires a minimally invasive procedure, thus representing an enormous reservoir for biomarkers discovery, for both diagnostic and prognostic applications. Many genome-wide profiling studies of circulating ncRNAs have been performed. Among miRNAs, heart and muscle-enriched miRNAs, also named myomiRs (miR-1-3p, miR-133a-3p, miR133b-3p, miR-208a/b-3p, and miR-499-5p) seem to be particularly relevant [105-110].

Indeed, in patients with AMI, myomiRs have been reported to be elevated in plasma, likely due to cardiomyocyte necrosis and thus released into the circulating system [111, 112]. Accordingly, miR-208a-3p and miR499-5p were also elevated in the plasma of viral-cardiomyopathy patients and their levels correlated positively with myocardial damage assessed by measuring Troponin $\mathrm{T}$ levels [113]. Among myomiRs, miR-208 is of particular interest, since its expression is highly cardiacspecific. Moreover, Voellenkle et al., analyzing the pattern of expression of peripheral blood mononuclear cells (PBMCs) identified a miRNA signature characterizing DCM patients [109].

Also lncRNAs can be found in the peripheral blood and hold a promising biomarker potential. The expression of LIPCAR (long intergenic noncoding RNA predicting cardiac remodeling) in plasma has been found to be correlated to cardiac remodeling progression after AMI $[114,115]$. Other potential biomarkers are MIAT (myocardial infarction associated transcript), discriminating ST-elevation from non ST-elevation AMI [116], SENCR (smooth muscle and endothelial cell-enriched migration/ differentiation-associated long noncoding RNA), associated to LV remodeling [117], as well as NRON (noncoding repressor of NFAT) and MHRT (Myosin Heavy Chain Associated RNA Transcripts), lncRNAs elevated in HF patients and independent predictors of HF events [117, 118]. Greco et al. [102], analyzing ICM patients found that ANRIL, HOTAIR, and LOC285194/TUSC7 had similar modulation in PBMC and heart tissue, suggesting a potential role as functional biomarkers. 
Among circRNAs, MICRA (myocardial infarctionassociated circular RNA) levels in the blood are associated with ischemic HF [119], while hsa_circ_0124644 and hsa-circ-0005870 are potential diagnostic biomarkers of coronary artery disease [120] and hypertension [121] respectively (Fig. 4b).

\section{Transcriptomics studies of SARS-CoVs infection: focus on inflammation}

The SARS-CoV-2 host-response transcriptomics changes have just started to be investigated, but reports on them are increasing over time.

\section{Peripheral blood}

The gene expression profile of blood samples derived from COVID-19 patients not only allows the definition of the host responses to the infection and, thus, a better understanding of the disease pathogenesis, but also the identification of potential biomarkers that could help monitoring patient responses to the disease.

Specifically, a distinct pattern of inflammatory cytokines was identified in bronchoalveolar lavage fluid and in the peripheral blood mononuclear cells, including CCL-2, -3 and -4 , and CXCL-10, as well as the activation of the P53 signaling-pathway in lymphocytes that may be related to COVID-19 lymphopenia [122]. In addition, several differential expressed transcripts were identified in PBMCs of COVID-19 patients with severe or mild symptoms [123] compared to controls. Cytokinemediated signaling, the natural killer cell mediated toxicity and $\mathrm{T}$ cell activation pathways were enriched terms in common between the two disease stages, while Interleukins- and TNF-signaling pathways were enriched terms

a

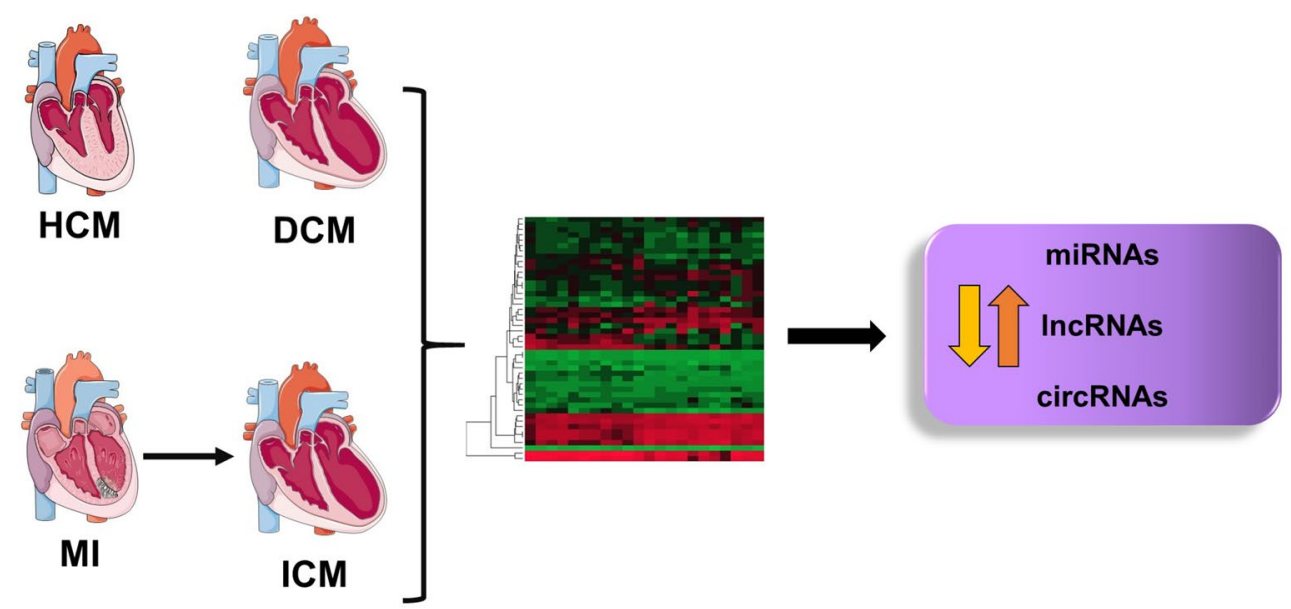

b
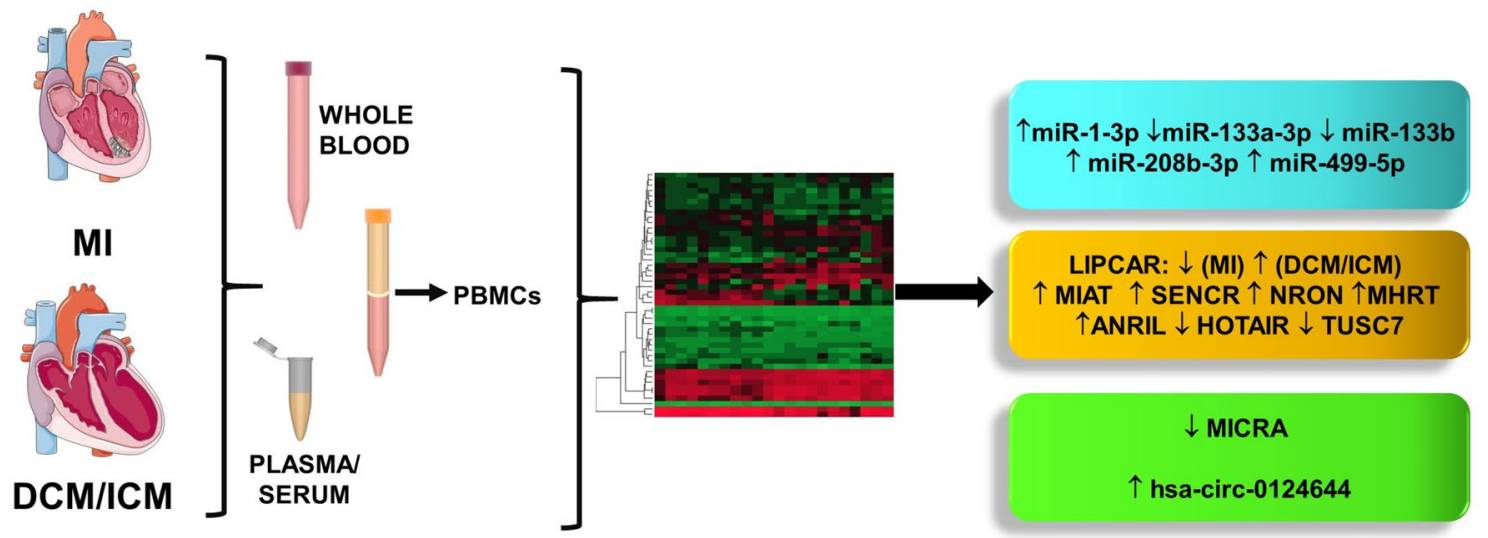

Fig. 4 Noncoding RNAs dysregulation studied by genome-wide transcriptomic analysis. a Analysis of the molecular modifications underlying both cardiac hypertropy (HCM) and remodeling (DCM and ICM) allowed the identification of dysregulated miRNAs, IncRNAs and circRNAs in the heart. $\mathbf{b}$ The release of ncRNAs by diseased cardiac tissues in the peripheral blood and the immunomodulation associated to CVD allowed the identification of dysregulated ncRNAs in whole blood, plasma/serum or in PBMCs, to be used as potential biomarkers 
specific for COVID-19 patients with severe symptoms [123].

Moreover, the single-cell RNA-sequencing (scRNAseq) approach has been used to profile the SARS-CoV-2 host-response in the PBMCs of COVID-19 patients, and to comprehensively characterize the immunological changes [124-130].

In eight COVID-19 patients, scRNA-seq of PBMC indicated the depletion of the innate immune subsets compared to healthy PBMC [125]. In addition, a new population, which was annotated as developing neutrophils' has been found increased only in patients with ARDS; this population expressed several genes in common with the neutrophil progenitors, but not canonical neutrophil markers, indicating that they could be neutrophils at various developmental stages [125]. The monocyte subset was enriched in CD14, but without a substantial expression of pro-inflammatory cytokine genes (TNF, IL6, IL1B, CCL3, CCL4 or CXCL2), which is in contrast with other reports $[124,126]$. Additionally, $\mathrm{CD} 14+$ monocytes showed the upregulation of a signature of interferon (IFN)-stimulated genes that correlated with clinically relevant parameters [125]. This strong activation of interferon-stimulated genes was also confirmed by Arunachalam et al. [127], primarily in patients with mild or moderate disease, that is associated to reduced expression of genes encoding proinflammatory cytokines [127]. Similarly, a more pronounced expression of type I IFN in mild COVID-19 patients and lack of IL1B mRNA levels increase were also confirmed in a recent study that analyzed by scRNA-seq two independent large cohorts of COVID-19 patients [128].

Conversely, an increased TNF/IL-1 $\beta$-driven inflammatory response was observed in severe COVID-19 patients as compared to severe influenza, and to mild COVID-19 patients [129].

The scRNA-seq approach has also been used to study the immune cell landscape of two severe-stage COVID19 patients prior to and following tocilizumab-induced remission [126]. In this study, a monocyte subpopulation that contributes to the inflammatory cytokine storms was identified. Bioinformatics analysis predicted a severe stage-specific interaction-networks formed by monocyte receptors and cytokines [126]. In addition, tocilizumab treatment in severe-stage COVID-19 patients led to an increased number of antibody-secreting plasma B cells, while CD8 + T cell-related cytotoxicity and cytokine production did not change [126]. These data provide insights into the understanding of the inflammatory storms observed in COVID-19 patients and identify also potential drug targets.

Zhang et al. analyzed by scRNA-seq the PBMCs of thirteen COVID-19 patients with clinical conditions ranging from moderate to severe and to convalescent [130]. Differentially expressed genes of CD14+and CD16+COVID-19 monocytes, especially in severe COVID-19 state, were associated with IFN responses, myeloid leukocyte activation, cytokine production and nuclear factor (NF) $-\kappa B$ signaling pathway [130]. Interestingly, in patients at the early phase of convalescence, despite of the recovery of most of the clinical parameters to a normal range, the immune system was still fully activated, as demonstrated by a still high naive $T$ and $T_{\text {reg }}$ subsets ratios [130].

Early and late stages of recovery have been analyzed in detail by Wen et al., confirming that COVID19 patients are still vulnerable after hospital discharge [124]. COVID-19 early recovery stage was characterized by $\mathrm{CD} 14++$ monocytes with high inflammatory gene expression as well as by the abundance of CD14++IL1 $\beta+$ cells, while $\mathrm{T}$ cells decreased remarkably, compared with both late recovery stage and healthy control subjects.

\section{Tissues}

Due to the limited cardiac tissue availability, data on SARS-CoV-2-mediated heart transcriptome changes have not been reported yet. However, SARS-CoV-2 infection of human induced pluripotent stem cell-derived cardiomyocytes (iPSC-CMs) induced cytotoxic effects and RNA-seq findings highlighted significant transcriptional changes in gene pathways related to cellular metabolism and immune response [131-133].

Indeed, Sharma et al. [131] observed in infected iPSCCMs a downregulation of transcriptional pathways related to mitochondrial function, oxidative phosphorylation, and cardiac function, whereas upregulated pathways included immune cytokines, immunomodulators, antiviral response, and apoptosis [131].

Accordingly, Bojkova and collaborators showed that SARS-COV-2 infection of iPSC-CMs induced cytotoxic and proapoptotic effects and abolished cardiomyocyte beating [132]. Virus infection produced a transcriptional response including the up-regulation of genes associated to viral response and interferon signaling, apoptosis and reactive oxygen stress [132]. On the same line, Pérez-Bermejo et al. [133], found that human iPSC-CMs exposed to SARS-CoV-2 demonstrated a productive infection and morphological signatures of damage, which included a distinct pattern of myofibrillar fragmentation and numerous iPSC-CMs lacking nuclear DNA. These morphological changes were also confirmed in human autopsy specimens from COVID-19 patients [133]. RNAseq transcriptomic data obtained in infected iPSC-CMs suggested a compensatory overexpression of myosin heavy chain genes in response to targeted degradation 
and also a significant depression of the ubiquitin-proteasome system upon infection [133].

As for the heart, a limited number of reports on lung transcriptomic changes mediated by SARS-CoV-2 infections has been published so far. One of the first studies on lung cells was the analysis of the transcriptional footprint in post-mortem lung samples of COVID-19 patients [134]. In this study a reduced IFN-I and -III response and a consistent chemokine signature compared to other respiratory viruses were observed [134].

The reanalysis of a previously reported dataset identified, as expected, upregulated expression of chemokines and neutrophils in the lung tissue and bronchoalveolar lavage fluid of COVID-19 patients and, in addition, the upregulation of genes coordinating heme biosynthesis [135]. This effect, which has been shown in sepsis secondary to pneumonia to have a protective role against oxidative stress [136], could be responsible of pro-inflammatory cytokine production amplification [137] or cause intravascular coagulation [138].

The possible involvement of altered coagulation following SARS-CoV-2 infection has been also proposed by a study analyzing three publicly available RNA sequencing datasets obtained from clinically isolated samples of bronchoalveolar lavage fluid, PBMCs and from in vitro SARS-CoV-2 infected primary normal human bronchial epithelial cells compared to the respective controls [139]. Gene expression analysis of both bronchoalveolar lavage and bronchial epithelial cells, but not of PBMCs, highlighted the activation of the extrinsic blood coagulation cascade and the suppression of the plasminogen activation system [139].

Moreover, a study performed in autopsy lung specimens from patients who succumbed to SARS-CoV-2 infection supported two phases of disease evolution in patients with severe COVID-19 pneumonia [140]. In the first phase, high expression of IFN pathway genes and of endothelial genes related to tissue damage and fibrosis were observed [140]. This first phase was morphologically characterized by high viral RNA, a histological pattern of exudative diffuse alveolar damage, a shorter disease duration, while the second phase showed a low (or undetectable) viral RNA, and an organizing form of diffuse alveolar damage [140].

Of note, the aforementioned pro-inflammatory cytokines, such as TNF- $\alpha$, IFN- $\gamma$, IL-1 $\beta$, IL- 6 , IL-17, and IL-18, are also elevated in HF and in viral myocarditis, and their sustained elevation correlates to HF progression. They are responsible for both compensatory cardiac hypertrophy and fibrosis in the setting of cardiac injury and induce further inflammation [141]. There are contrasting effects attributed to IFN- $\gamma$ in the heart. Upon adverse stimuli, such as myocarditis or hypertension, the release of IFN- $\gamma$ by recruited inflammatory cells to the heart results in cardiac fibrosis and hypertrophy. However, other studies have found that IFN- $\gamma$ has also protective effects, limiting cardiac hypertrophy [142]. The signaling of the pro-inflammatory cytokines is counterbalanced by the release of anti-inflammatory cytokines and TGF- $\beta$, which mitigate hypertrophic cardiac remodeling [141].

These data indicate that, along with the direct effect mediated by the virus, such as in myocarditis, the cardiac sequelae may be due to the cytokines storm following the infection, which reinforces the cytokines release, observed in dilated cardiomyopathies.

\section{Noncoding RNAs regulating inflammation and the cardiovascular system: are they playing a role in COVID-19?}

An over-activation of the inflammatory response and the ensuing cytokine storm seem to be a crucial pathogenetic mechanism in COVID-19 patients and, as illustrated in Sect. "Transcriptomics studies of SARS-CoVs infection: focus on inflammation", the innate immune response pathway has emerged as profoundly dysregulated in SARS-CoVs infections.

The immune system contributes to heart development, composition and function and, in specific circumstances, immune cells can also cause damage, participating to cardiac disease [143]. For instance, in patients with HF, a chronic activation of the innate immune system is often observed, with T-cells and macrophages myocardial infiltration and increased pro-inflammatory cytokine levels (i.e. TNF-a, IL-1b, and IL-6) [144].

NcRNAs are important regulators of these processes and we propose that ncRNAs may play a fundamental role also in the cardiovascular dysfunctions of COVID-19 patients.

As mentioned above, the expression of ACE2 is well known in adult cardiomyocytes [48, 53-55, 77], as well as in neonatal rat cardiomyocytes and in human IPSCCMs [145]. Bioinformatics analysis predicted miR-200b, miR-200c and miR-429 among the miRNAs targeting ACE2, and in vitro experiments demonstrated that miR-200c modulation regulated the expression of ACE2 [145]. MiR-200c is upregulated by oxidative stress [146] and is also involved in CVDs [146], suggesting that miR200c-mediated regulation of ACE2 may be important for SARS-CoV-2 entry.

Computational analyses have predicted that SARS$\mathrm{CoV}-2$ can divert the cellular miRNAs from their transcriptional regulating activity, contributing to the abnormal immunity activation in patients with COVID19 [147], or synthesizes its own viral miRNAs to 
reduce the host cell apoptosis preventing host defense [147-149].

On the other side, host miRNAs were predicted to target SARS-CoV-2 spike proteins, suggesting a potential role as therapeutic molecules $[149,150]$.

Direct or indirect effects of SARS-CoV-2 infection can alter host response and produce noncoding RNA differential expression. In particular, in bronchial epithelial cells infected with SARS-Cov-2, a complex bioinformatics and computational pipeline, revealed several activated networks, including those involved in immunoglobulin $\mathrm{G}$ and interferon lambda [151]. In addition, acute inflammatory response and activation of TNF were also observed. This analysis also revealed several host-derived lncRNAs differentially expressed in COVID-19 patient-derived lung tissue, and in SARSCoV-2 infected epithelial cells, including MALAT1 (metastasis-associated lung adenocarcinoma transcript 1) and NEAT1 (nuclear-enriched autosomal transcript 1) [151] (Fig. 5).

The computational reanalysis of RNA-Seq dataset of SARS-CoV-2 infected bronchial epithelial cells [134] identified several protein-coding RNAs and lncRNAs differentially modulated [152]. The interaction of lncRNAs with the differentially expressed protein-coding genes was analyzed by network enrichment analysis indicating significant interactions involved in cellular signaling, metabolism, immune response and RNA homeostasis [152].

The RNA-Seq of RNA extracted from peripheral blood samples from 10 COVID-19 patients compared to 4 controls demonstrated that 35 miRNAs were upregulated and 38 miRNAs were downregulated in the human patients with COVID-19 [153]. Enrichment analysis of differentially expressed miRNA target genes revealed that peptidases, protein kinases, and the ubiquitin system were shown to be the highest enrichment categories [153] (Fig. 5).

There are also some hints provided by transcriptomics studies on SARS-CoV. When this infection had a multicountry outbreak in 2002 to 2003, coding RNAs were still the focus of attention for the scientific community and microarrays were the preferential profiling tool. Nevertheless, some studies performed in the following years on lung samples or on bronchoalveolar stem cells collected from mouse infected with adapted SARS-CoV are available [154-157]. These studies identified lncRNAs and miRNAs involved in innate immune response in CVDs.

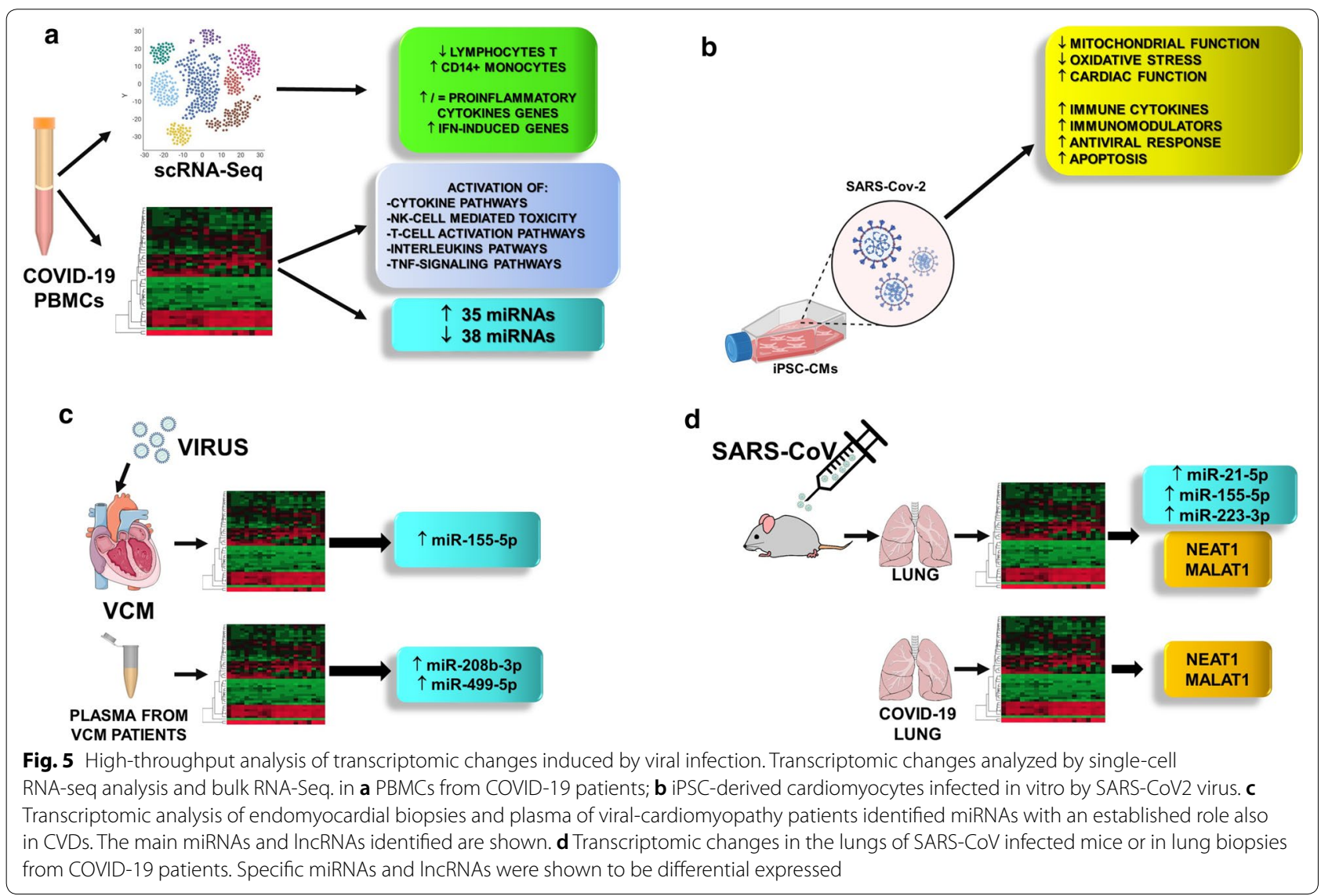


In particular, the lncRNAs Neat1 (nuclear paraspeckle assembly transcript 1) and Malat1 (metastasis-associated lung adenocarcinoma transcript 1) [154] were up- and down-regulated after infection, respectively, and miR155-5p [156], miR-21-5p and miR-223-3p were among the most deregulated miRNAs upon SARS-CoV infection (Fig. 5).

MiR-155-5p, miR-223-3p and miR-21-5p are expressed in immune cells and involved in both innate immune response $[158,159]$ and in myocardial infarction or HF $[10,86-88,158-161]$. These miRNAs control the production and secretion of pro-inflammatory cytokines in the heart by Toll-like (TRL) receptors and their downstream signaling pathway, which involves the transcription nuclear factor-kappa B (NF-kB). Indeed, miR-155-5p, along with miR-146a-5p, represents a unique regulatory network for the fine-tuning of the macrophage inflammatory response via regulation of NF-kB activity [162]. In particular, the activation of NF- $\mathrm{kB}$ by a stressor stimulates miR-155-5p expression which, amplifying NF- $\mathrm{kB}$ activity, enables a strong macrophage activation. As the inflammatory response develops, miR-146a-5p transcription increases, inhibiting its targets IRAK1 and TRAF6, whereby dampening NF- $\mathrm{kB}$ activation (Fig. 5).

In addition, also miR-21-5p targets a component of the NF- $\mathrm{kB}$ pathway, PDCD4 (Programmed Cell Death 4), thus stimulating the release of pro-inflammatory cytokines and inhibiting the release of anti-inflammatory cytokines $[163,164]$.

Finally, miR-223-3p seems to have cardio-protective and anti-inflammatory roles by enhancing glucose metabolism and inhibiting granulocyte activation. Accordingly, a decrease of miR-223-3p levels in tissue and plasma has been observed in diabetes and CVDs [95, 165-167].

Another ncRNA of relevance in cardio-immunology is the lncRNA NEAT1, which was reported to induce intima thickening in vascular smooth muscle cells [168]. NEAT1 is also part of the innate immune response by promoting the activation of the inflammasome in macrophages and the release of IL-1 $\beta$ [169].

Together, these data indicate that some of the ncRNAs reported to be dysregulated by transcriptomic profiling in CVDs, are also involved in viral innate immune responses, and that they may be identified as candidate transcripts for our query in understanding the pathogenesis of COVID-19.

\section{Conclusions and perspectives}

Investigating the interplay between SARS-CoV-2, the host antiviral defenses and the cardiovascular system, is fundamental to understand the viral pathogenesis and the infection outcome. Indications from SARS-CoV and other coronaviruses are very helpful; however, SARS$\mathrm{CoV}-2$ is a novel human pathogen and many aspects of its interaction with the host could be unique.

It is now clear that pre-existing CVDs increase both the severity of the primary respiratory syndrome and the risk of adverse outcomes. SARS-CoV-2 infection consequences on the cardiovascular system should be investigated both for their acute and prolonged sequelae. In this view, transcriptomics may be a powerful approach to study the ncRNA involvement in the disease mechanisms and for the identification of biomarkers.

Significant hurdles are represented by difficulties in measuring and studying ncRNAs due to low abundance of many of them or to specific structural features (e.g. circRNAs). Identification of RNA-based biomarkers and targets requires heavy reliance on relatively expensive sequencing approaches that still lack universally adopted standard operative procedures [10, 23, 170]. Insufficient structural and functional annotation of the noncoding genome is also a significant problem. These limitations should be overcome in order to make significant scientific progresses in our understanding of COVID-19 pathogenesis, facilitating prognosis and hopefully, paving the way to potential therapeutic approaches.

In this respect, international cooperation to share knowledge, patient samples and data collection across many institutes and countries seems as an almost obligatory strategy [171].

\section{Abbreviations}

ACE2: Angiotensin-converting enzyme 2; AMl: Acute myocardial infarction; ARDS: Acute respiratory distress syndrome; circRNAs: Circular RNAs; COVID-19: CoronaVIrus Disease 19; CVDs: Cardiovascular diseases; DCM: Dilated cardiomyopathy; HF: Heart failure; ICM: Ischemic cardiomyopathy; IFN: Interferon; IL: Interleukin; IncRNAs: Long noncoding RNAs; MERS-CoV: Middle East respiratory syndrome-coronavirus; miRNAs: MicroRNAs; mRNAs: Messenger RNAs; ncRNAs: Noncoding RNAs; NF-kb: Nuclear factor-kappa B; PBMCs: Peripheral blood mononuclear cells; SARS-CoV: Severe acute respiratory syndromecoronavirus; STAT1: Signal transducer and activator of transcription 1; TGF: Transforming growth factor; TNF-a: Tumor necrosis factor-a.

\section{Acknowledgements}

We are thankful to Jeremy C. Hill (Imperial College London) for editorial assistance. Figures were partly generated by using Biorender App and https:// www.somersault1824.com/science-illustrations/.

\section{Authors' contributions}

All authors contributed to the conception, design and revision of the article. SG, AM and FM wrote most of the text and prepared the figures. CG, YD and CE contributed with bibliographic searches, writing of specific paragraphs, suggestions and expert critical reading. All authors have read and agreed to the published version of the manuscript. All authors read and approved the final manuscript.

\section{Funding}

F.M.and S.G. are supported by the Italian Ministry of Health, ("Ricerca Corrente and $5 \times 1000$ ) and F.M. by Telethon Foundation (GGP19035A) and AFM-

Telethon grant (23054). Y.D. is funded by the National Research Fund (grants \# C14/BM/8225223 and C17/BM/11613033), the Ministry of Higher Education 
and Research, and the Fondation Coeur - Daniel Wagner of Luxembourg. CG is supported by Ricerca Corrente Ministero della Salute; Ricerca Corrente di Rete "Aging" Ministero della Salute; Progetto Regione Lombardia Immunhub. C.E. s funded by British Heart Foundation Programme Grant (RG/15/5/31446) and Personal Chair (CH/15/1/31199). This publication is based upon work from the COST ACTION CardioRNA CA17129, supported by COST (European Cooperation in Science and Technology).

\section{Availability of data and materials \\ Not applicable.}

\section{Ethics approval and consent to participate}

Not applicable.

\section{Consent for publication}

Not applicable.

\section{Competing interest}

The authors declare no conflict of interest. The funders had no role in the design, execution, interpretation, or writing of the study.

\begin{abstract}
Author details
1 Molecular Cardiology Laboratory, IRCCS Policlinico San Donato, San Donato Milanese, 20097 Milan, Italy. ${ }^{2}$ Laboratory of Epigenetics, Istituti Clinici Scientifici Maugeri IRCCS, 27100 Pavia, Italy. ${ }^{3}$ Cardiovascular Research Unit, Luxembourg Institute of Health, Strassen, Luxembourg. ${ }^{4}$ Imperial College London, National Heart and Lung Institute, Hammersmith Campus, London W12 ONN, UK.
\end{abstract}

Received: 23 June 2020 Accepted: 24 October 2020

Published online: 31 October 2020

\section{References}

1. Wang C, Horby PW, Hayden FG, Gao GF. A novel coronavirus outbreak of Global Health Concern. Lancet. 2020;395:470-3.

2. Whitworth J. COVID-19: A Fast Evolving Pandemic. Trans R Soc Trop Med Hyg. 2020;114:241-8.

3. WHO Coronavirus Disease (COVID-19) Dashboard https://covid19.Who. Int/., 2020.

4. Huang C, Wang Y, Li X, Ren L, Zhao J, Hu Y, Zhang L, Fan G, Xu J, Gu X, et al. Clinical features of patients infected with 2019 novel coronavirus in Wuhan. China Lancet. 2020;395:497-506.

5. Wang D, Hu B, Hu C, Zhu F, Liu X, Zhang J, Wang B, Xiang H, Cheng Z, Xiong $Y$, et al. Clinical characteristics of 138 hospitalized patients with 2019 novel coronavirus-infected pneumonia in Wuhan China. JAMA. 2020;323:1061-9.

6. Chen N, Zhou M, Dong X, Qu J, Gong F, Han Y, Qiu Y, Wang J, Liu Y, Wei $Y$, et al. Epidemiological and clinical characteristics of 99 cases of 2019 novel coronavirus pneumonia in Wuhan, China: A Descriptive Study. Lancet. 2020;395:507-13.

7. Xiong TY, Redwood S, Prendergast B, Chen M. Coronaviruses and the Cardiovascular System: Acute and Long-Term Implications. Eur Heart J. 2020;41:1798-800.

8. Zheng YY, Ma YT, Zhang JY, Xie X. COVID-19 and the Cardiovascular System. Nat Rev Cardiol. 2020;17:259-60.

9. Guo, T.; Fan, Y.; Chen, M.; Wu, X.; Zhang, L.; He, T.; Wang, H.; Wan, J.; Wang, X.; Lu, Z. Cardiovascular Implications of Fatal Outcomes of Patients with Coronavirus Disease 2019 (COVID-19). JAMA Cardiol. 2020.

10. Gomes CPC, Schroen B, Kuster GM, Robinson EL, Ford K, Squire IB, Heymans S, Martelli F, Emanueli C, Devaux Y, et al. Regulatory RNAs in Heart Failure. Circulation. 2020;141:313-28.

11. Venter JC, Adams MD, Myers EW, Li PW, Mural RJ, Sutton GG, Smith HO, Yandell M, Evans CA, Holt RA, et al. The Sequence of the Human Genome. Science. 2001;291:1304-51.

12. Frith MC, Pheasant M, Mattick JS. The Amazing Complexity of the Human Transcriptome. Eur J Hum Genet. 2005;13:894-7.

13. Sullenger BA, Nair S. From the RNA World to the Clinic. Science. 2016:352:1417-20.
14. Lee Y, Kim M, Han J, Yeom KH, Lee S, Baek SH, Kim VN. MicroRNA Genes are Transcribed by RNA Polymerase II. EMBO J. 2004;23:4051-60.

15. Carthew RW, Sontheimer EJ. Origins and Mechanisms of miRNAs and siRNAs. Cell. 2009;136:642-55.

16. Ambros V. microRNAs: Tiny Regulators with Great Potential. Cell. 2001;107:823-6.

17. Flynt AS, Lai EC. Biological principles of microRNA-mediated regulation: shared themes amid diversity. Nat Rev Genet. 2008;9:831-42.

18. Bartel DP. Metazoan MicroRNAs. Cell. 2018;173:20-51.

19. Friedman RC, Farh KK, Burge CB, Bartel DP. Most Mammalian mRNAs are Conserved Targets of microRNAs. Genome Res. 2009;19:92-105.

20. Spitale RC, Tsai MC, Chang HY. RNA Templating the Epigenome: Long Noncoding RNAs as Molecular Scaffolds. Epigenetics. 2011;6:539-43.

21. Mattick JS, Amaral PP, Dinger ME, Mercer TR, Mehler MF. RNA Regulation of Epigenetic Processes. Bioessays. 2009;31:51-9.

22. Bergmann JH, Spector DL. Long non-coding RNAs: modulators of nuclear structure and function. Curr Opin Cell Biol. 2014;26:10-8.

23. Greco S, Salgado Somoza A, Devaux Y, Martelli F. Long noncoding RNAs and cardiac disease. Antioxid Redox Signal. 2018;29:880-901.

24. Hangauer MJ, Vaughn IW, McManus MT. Pervasive transcription of the human genome produces thousands of previously unidentified long intergenic noncoding RNAs. PLoS Genet. 2013;9:e1003569.

25. Kapranov P, Cheng J, Dike S, Nix DA, Duttagupta R, Willingham AT, Stadler PF, Hertel J, Hackermuller J, Hofacker IL, et al. RNA maps reveal new RNA classes and a possible function for pervasive transcription. Science. 2007;316:1484-8.

26. Greco, S.; Cardinali, B.; Falcone, G.; Martelli, F. Circular RNAs in Muscle Function and Disease. Int. J. Mol. Sci. 2018, 19, https://doi.org/10.3390/ ijms19113454.

27. Lee JT. Epigenetic Regulation by Long Noncoding RNAs. Science. 2012:338:1435-9.

28. Gandelman, M.; Dansithong, W.; Figueroa, K.P.; Paul, S.; Scoles, D.R.; Pulst, S.M. Staufen 1 Amplifies Proapoptotic Activation of the Unfolded Protein Response. Cell Death Differ. 2020.

29. Yoon JH, Abdelmohsen K, Srikantan S, Yang X, Martindale JL, De S, Huarte M, Zhan M, Becker KG, Gorospe M. LincRNA-p21 Suppresses Target mRNA Translation. Mol Cell. 2012;47:648-55.

30. Greco, S.; Gaetano, C.; Martelli, F. Long Noncoding Competing Endogenous RNA Networks in Age-Associated Cardiovascular Diseases. Int. J. Mol. Sci. 2019, 20, https://doi.org/10.3390/ijms20123079.

31. Cesana M, Cacchiarelli D, Legnini I, Santini T, Sthandier O, Chinappi M, Tramontano A, Bozzoni I. A Long Noncoding RNA Controls Muscle Differentiation by Functioning as a Competing Endogenous RNA. Cell. 2011;147:358-69.

32. Chen Y, Liu Q, Guo D. Emerging coronaviruses: genome structure, replication, and pathogenesis. J Med Virol. 2020;92:418-23.

33. Kandeel M, Ibrahim A, Fayez M, Al-Nazawi M. From SARS and MERS CoVs to SARS-COV-2: moving toward more biased codon usage in viral structural and nonstructural genes. J Med Virol. 2020;92:660-6.

34. Hulswit RJ, de Haan CA, Bosch BJ. Coronavirus spike protein and tropism changes. Adv Virus Res. 2016;96:29-57.

35. Risco C, Anton IM, Enjuanes L, Carrascosa JL. The transmissible gastroenteritis coronavirus contains a spherical core shell consisting of $\mathrm{M}$ and N proteins. J Virol. 1996;70:4773-7.

36. Ruch TR, Machamer CE. The Coronavirus E protein: assembly and beyond. Viruses. 2012;4:363-82.

37. Neuman BW, Kiss G, Kunding AH, Bhella D, Baksh MF, Connelly S, Droese B, Klaus JP, Makino S, Sawicki SG, et al. A structural analysis of M protein in Coronavirus assembly and morphology. J Struct Biol. 2011;174:11-22.

38. Hagemeijer MC, Verheije MH, Ulasli M, Shaltiel IA, de Vries LA, Reggiori F, Rottier PJ, de Haan CA. Dynamics of Coronavirus replication-transcription complexes. J Virol. 2010;84:2134-49.

39. Yin Y, Wunderink RG. MERS, SARS and other Coronaviruses as causes of Pneumonia. Respirology. 2018;23:130-7.

40. Cui J, Li F, Shi ZL. Origin and evolution of pathogenic Coronaviruses. Nat Rev Microbiol. 2019;17:181-92.

41. Corman VM, Muth D, Niemeyer D, Drosten C. Hosts and sources of endemic human coronaviruses. Adv Virus Res. 2018;100:163-88.

42. Zhou P, Yang XL, Wang XG, Hu B, Zhang L, Zhang W, Si HR, Zhu Y, Li B, Huang $C L$, et al. A Pneumonia outbreak associated with a new coronavirus of probable bat origin. Nature. 2020;579:270-3. 
43. Adhikari, S.P.; Meng, S.; Wu, Y.J.; Mao, Y.P.; Ye, R.X.; Wang, Q.Z.; Sun, C.; Sylvia, S.; Rozelle, S.; Raat, H. et al. Epidemiology, Causes, Clinical Manifestation and Diagnosis, Prevention and Control of Coronavirus Disease (COVID-19) during the Early Outbreak Period: A Scoping Review. Infect. Dis. Poverty 2020, 9, 29-020-00646-X.

44. Ren LL, Wang YM, Wu ZQ, Xiang ZC, Guo L, Xu T, Jiang YZ, Xiong Y, Li YJ, $\mathrm{Li} X W$, et al. Identification of a novel coronavirus causing severe pneumonia in human: a descriptive study. Chin Med J. 2020;133:1015-24.

45. Xu, J.; Zhao, S.; Teng, T.; Abdalla, A.E.; Zhu, W.; Xie, L.; Wang, Y.; Guo, X. Systematic Comparison of Two Animal-to-Human Transmitted Human Coronaviruses: SARS-CoV-2 and SARS-CoV. Viruses 2020, 12, https://doi. org/10.3390/v12020244

46. Lin, L.; Lu, L.; Cao, W.; Li, T. Hypothesis for Potential Pathogenesis of SARS-CoV-2 Infection-a Review of Immune Changes in Patients with Viral Pneumonia. Emerg. Microbes Infect. 2020, 1-14.

47. Letko M, Marzi A, Munster V. Functional assessment of cell entry and receptor usage for SARS-CoV-2 and other lineage B betacoronaviruses. Nat Microbiol. 2020;5:562-9.

48. Yan R, Zhang Y, Li Y, Xia L, Guo Y, Zhou Q. Structural basis for the recognition of the SARS-CoV-2 by full-length human ACE2. Science. 2020;367:1444-8.

49. Keidar S, Kaplan M, Gamliel-Lazarovich A. ACE2 of the Heart: From Angiotensin I to Angiotensin (1-7). Cardiovasc Res. 2007;73:463-9.

50. Akhmerov, A.; Marban, E. COVID-19 and the Heart. Circ. Res. 2020.

51. Peiris JS, Chu CM, Cheng VC, Chan KS, Hung IF, Poon LL, Law KI, Tang BS, Hon TY, Chan CS, et al. Clinical progression and viral load in a community outbreak of coronavirus-associated SARS pneumonia: A prospective study. Lancet. 2003;361:1767-72.

52. White NJ. Cardiotoxicity of antimalarial drugs. Lancet Infect Dis. 2007;7:549-58.

53. Hoffmann M, Kleine-Weber $\mathrm{H}$, Schroeder $\mathrm{S}$, Kruger N, Herrler T, Erichsen S, Schiergens TS, Herrler G, Wu NH, Nitsche A, et al. SARS-CoV-2 cell entry depends on ACE2 and TMPRSS2 and is blocked by a clinically proven protease inhibitor. Cell. 2020;181(271-280):e8.

54. Gheblawi M, Wang K, Viveiros A, Nguyen Q, Zhong JC, Turner AJ, Raizada MK, Grant MB, Oudit GY. Angiotensin converting enzyme 2: SARS-CoV-2 receptor and regulator of the renin-angiotensin system. Circ Res. 2020;126:1456-74.

55. Kuba K, Imai Y, Rao S, Gao H, Guo F, Guan B, Huan Y, Yang P, Zhang Y, Deng $W$, et al. A crucial role of angiotensin converting enzyme 2 (ACE2) in SARS coronavirus-induced lung injury. Nat Med. 2005;11:875-9.

56. Zhu, Y.; Jiang, M.; Gao, L.; Huang, X. Single Cell Analysis of ACE2 Expression Reveals the Potential Targets for 2019-nCoV. Preprints 2020.

57. Patel VB, Mori J, McLean BA, Basu R, Das SK, Ramprasath T, Parajuli N, Penninger JM, Grant MB, Lopaschuk GD, et al. ACE2 Deficiency Worsens Epicardial Adipose Tissue Inflammation and Cardiac Dysfunction in Response to Diet-Induced Obesity. Diabetes. 2016;65:85-95.

58. Crackower MA, Sarao R, Oudit GY, Yagil C, Kozieradzki I, Scanga SE, Oliveira-dos-Santos AJ, da Costa J, Zhang L, Pei Y, et al. AngiotensinConverting Enzyme 2 is an Essential Regulator of Heart Function. Nature. 2002;417:822-8.

59. Ferrario, C.M. Myocardial Infarction Increases ACE2 Expression in Rat and Humans. Eur. Heart J. 2005, 26, 1141; author reply 1141-3.

60. Goulter, A.B.; Goddard, M.J.; Allen, J.C.; Clark, K.L. ACE2 Gene Expression is Up-Regulated in the Human Failing Heart. BMC Med. 2004, 2 19-7015-2-19.

61. Anguiano L, Riera M, Pascual J, Soler MJ. Circulating ACE2 in cardiovascular and kidney diseases. Curr Med Chem. 2017;24:3231-41.

62. Farcas GA, Poutanen SM, Mazzulli T, Willey BM, Butany J, Asa SL, Faure P, Akhavan P, Low DE, Kain KC. Fatal Severe Acute Respiratory Syndrome is Associated with Multiorgan Involvement by Coronavirus. J Infect Dis. 2005;191:193-7.

63. Tang JW, To KF, Lo AW, Sung JJ, Ng HK, Chan PK. Quantitative temporal-spatial distribution of severe acute respiratory syndromeassociated coronavirus (SARS-CoV) in post-mortem tissues. J Med Virol. 2007:79:1245-53.

64. Oudit GY, Kassiri Z, Jiang C, Liu PP, Poutanen SM, Penninger JM, Butany J. SARS-coronavirus modulation of myocardial ACE2 expression and inflammation in patients with SARS. Eur J Clin Invest. 2009;39:618-25.

65. Watkins J. Preventing a Covid-19 Pandemic. BMJ. 2020;368:m810.
66. Kuster GM, Pfister O, Burkard T, Zhou Q, Twerenbold R, Haaf P, Widmer AF, Osswald S. SARS-CoV2: should Inhibitors of the Renin-Angiotensin System be Withdrawn in Patients with COVID-19? Eur Heart J. 2020;41:1801-3.

67. Conversano, A.; Melillo, F.; Napolano, A.; Fominskiy, E.; Spessot, M.; Ciceri, F.; Agricola, E. RAAs Inhibitors and Outcome in Patients with SARSCoV-2 Pneumonia. A Case Series Study. Hypertension 2020.

68. Liu Y, Yang Y, Zhang C, Huang F, Wang F, Yuan J, Wang Z, Li J, Li J, Feng C, et al. Clinical and biochemical indexes from 2019-nCoV infected patients linked to viral loads and lung injury. Sci China Life Sci. 2020;63:364-74.

69. Ruan Q, Yang K, Wang W, Jiang L, Song J. Clinical Predictors of Mortality due to COVID-19 Based on an Analysis of Data of 150 Patients from Wuhan China. Intensive Care Med. 2020:46:846-8.

70. Lippi G, Sanchis-Gomar F. Cardiac Troponin I in Patients with Coronavirus Disease 2019 (COVID-19): Evidence from a Meta-Analysis. Dis: Prog. Cardiovasc; 2020.

71. Alexander LK, Keene BW, Small JD, Yount B, Baric RS. Electrocardiographic changes following rabbit coronavirus-induced myocarditis and dilated cardiomyopathy. Adv Exp Med Biol. 1993;342:365-70.

72. Alhogbani T. Acute myocarditis associated with novel middle east respiratory syndrome coronavirus. Ann Saudi Med. 2016;36:78-80.

73. Tavazzi G, Pellegrini C, Maurelli M, Belliato M, Sciutti F, Bottazzi A, Sepe PA, Resasco T, Camporotondo R, Bruno R, et al. Myocardial Localization of Coronavirus in COVID-19 Cardiogenic Shock. Eur J Heart Fail. 2020;22:911-5.

74. Xu Z, Shi L, Wang Y, Zhang J, Huang L, Zhang C, Liu S, Zhao P, Liu H, Zhu L, et al. Pathological Findings of COVID-19 associated with acute respiratory distress syndrome. Lancet Respir. Med. 2020;8:420-2.

75. Sala S, Peretto G, Gramegna M, Palmisano A, Villatore A, Vignale D, De Cobelli F, Tresoldi M, Cappelletti AM, Basso C, et al. Acute Myocarditis presenting as a reverse tako-tsubo syndrome in a patient with SARSCoV-2 respiratory infection. Eur Heart J. 2020;41:1861-2.

76. Li SS, Cheng CW, Fu CL, Chan YH, Lee MP, Chan JW, Yiu SF. Left ventricular performance in patients with severe acute respiratory syndrome: a 30-day echocardiographic follow-up study. Circulation. 2003;108:1798-803.

77. Singh M, Bansal V, Feschotte C. A single-cell RNA expression map of human coronavirus entry factors. Cell Rep. 2020;32:108175.

78. Huang KJ, Su IJ, Theron M, WU YC, Lai SK, Liu CC, Lei HY. An InterferonGamma-Related Cytokine Storm in SARS Patients. J Med Virol. 2005;75:185-94.

79. Kwong JC, Schwartz KL, Campitelli MA. Acute myocardial infarction after laboratory-confirmed influenza infection. N Engl J Med. 2018;378:2540-1.

80. Jackson SP, Darbousset R, Schoenwaelder SM. Thromboinflammation: challenges of therapeutically targeting coagulation and other host defense mechanisms. Blood. 2019;133:906-18.

81. Varga ZV, Ferdinandy P, Liaudet L, Pacher P. Drug-induced mitochondrial dysfunction and cardiotoxicity. Am J Physiol Heart Circ Physiol. 2015;309:H1453-67.

82. Siripanthong B, Nazarian S, Muser D, Deo R, Santangeli P, Khanji MY, Cooper LT, Chahal CAA. Recognizing COVID-19-Related myocarditis: the possible pathophysiology and proposed guideline for diagnosis and management. Heart Rhythm. 2020;17:1463-71.

83. Yang J, Zheng Y, Gou X, Pu K, Chen Z, Guo Q, Ji R, Wang H, Wang Y, Zhou $Y$. Prevalence of comorbidities in the novel Wuhan Coronavirus (COVID19) infection: a systematic review and meta-analysis. Int J Infect Dis. 2020;94:91-5.

84. Wang, T.; Du, Z.; Zhu, F.; Cao, Z.; An, Y.; Gao, Y.; Jiang, B. Comorbidities and Multi-Organ Injuries in the Treatment of COVID-19. Lancet 2020, 395, e52-6736(20)30558-4. Epub 2020 Mar 11.

85. Wu, Q.; Zhou, L.; Sun, X.; Yan, Z.; Hu, C.; Wu, J.; Xu, L.; Li, X.; Liu, H.; Yin, P. et al. Altered Lipid Metabolism in Recovered SARS Patients Twelve Years After Infection. Sci. Rep. 2017, 7, 9110-017-09536-z.

86. Lu D, Thum T. RNA-based diagnostic and therapeutic strategies for cardiovascular disease. Nat Rev Cardiol. 2019;16:661-74.

87. Barwari T, Joshi A, Mayr M. MicroRNAs in Cardiovascular Disease. J Am Coll Cardiol. 2016;68:2577-84

88. Greco S, Gorospe M, Martelli F. Noncoding RNA in age-related cardiovascular diseases. J Mol Cell Cardiol. 2015;83:142-55. 
89. Greco, S.; Gaetano, C.; Martelli, F. Long Noncoding Competing Endogenous RNA Networks in Age-Associated Cardiovascular Diseases. Int. J. Mol. Sci. 2019, 20, https://doi.org/10.3390/ijms20123079.

90. Nanni L, Romualdi C, Maseri A, Lanfranchi G. Differential Gene Expression Profiling in Genetic and Multifactorial Cardiovascular Diseases. J Mol Cell Cardiol. 2006;41:934-48.

91. Margulies KB, Bednarik DP, Dries DL. Genomics, Transcriptional Profiling, and Heart Failure. J Am Coll Cardiol. 2009;53:1752-9.

92. Sucharov C, Bristow MR, Port JD. miRNA Expression in the Failing Human Heart: functional Correlates. J Mol Cell Cardiol. 2008;45:185-92.

93. Funahashi $\mathrm{H}$, Izawa $\mathrm{H}$, Hirashiki A, Cheng XW, Inden Y, Nomura M, Murohara T. Altered microRNA Expression Associated with Reduced Catecholamine Sensitivity in Patients with Chronic Heart Failure. J Cardiol. 2011;57:338-44.

94. Sucharov CC, Kao DP, Port JD, Karimpour-Fard A, Quaife RA, Minobe W, Nunley K, Lowes BD, Gilbert EM, Bristow MR. Myocardial microRNAs Associated with Reverse Remodeling in Human Heart Failure. JCI Insight. 2017;2:e89169.

95. Greco S, Fasanaro P, Castelvecchio S, D'Alessandra Y, Arcelli D, Di Donato M, Malavazos A, Capogrossi MC, Menicanti L, Martelli F. MicroRNA Dysregulation in Diabetic Ischemic Heart Failure Patients. Diabetes. 2012;61:1633-41.

96. Liu YL, Wu W, Xue Y, Gao M, Yan Y, Kong Q, Pang Y, Yang F. MicroRNA-21 and $-146 \mathrm{~b}$ are Involved in the Pathogenesis of Murine Viral Myocarditis by Regulating TH-17 Differentiation. Arch Virol. 2013;158:1953-63.

97. Kuhl U, Rohde M, Lassner D, Gross UM, Escher F, Schultheiss HP. miRNA as Activity Markers in Parvo B19 Associated Heart Disease. Herz. 2012;37:637-43.

98. Corsten MF, Papageorgiou A, Verhesen W, Carai P, Lindow M, Obad S, Summer G, Coort SL, Hazebroek M, van Leeuwen R, et al. MicroRNA Profiling Identifies microRNA-155 as an Adverse Mediator of Cardiac Injury and Dysfunction during Acute Viral Myocarditis. Circ Res. 2012;111:415-25.

99. Archer K, Broskova Z, Bayoumi AS, Teoh JP, Davila A, Tang Y, Su H, Kim IM. Long Non-Coding RNAs as Master Regulators in Cardiovascular Diseases. Int J Mol Sci. 2015;16:23651-67.

100. Sallam T, Sandhu J, Tontonoz P. Long Noncoding RNA Discovery in Cardiovascular Disease: decoding Form to Function. Circ Res. 2018;122:155-66.

101. Philippen LE, Dirkx E, da Costa-Martins PA, De Windt LJ. Non-Coding RNA in Control of Gene Regulatory Programs in Cardiac Development and Disease. J Mol Cell Cardiol. 2015;89:51-8.

102. Greco, S.; Zaccagnini, G.; Perfetti, A.; Fuschi, P.; Valaperta, R.; Voellenkle, C.; Castelvecchio, S.; Gaetano, C.; Finato, N.; Beltrami, A.P. et al. Long Noncoding RNA Dysregulation in Ischemic Heart Failure. J. Transl. Med. 2016, 14, 183-016-0926-5.

103. Huang ZP, Ding Y, Chen J, Wu G, Kataoka M, Hu Y, Yang JH, Liu J, Drakos SG, Selzman CH, et al. Long non-coding RNAs link extracellular matrix gene expression to ischemic cardiomyopathy. Cardiovasc Res. 2016;112:543-54

104. Khan MA, Reckman YJ, Aufiero S, van den Hoogenhof MM, van der Made I, Beqqali A, Koolbergen DR, Rasmussen TB, van der Velden J, Creemers EE, et al. RBM20 Regulates Circular RNA Production from the Titin Gene. Circ Res. 2016;119:996-1003.

105. Busch A, Eken SM, Maegdefessel L. Prospective and therapeutic screening value of non-coding RNA as biomarkers in cardiovascular disease. Ann Transl Med. 2016:4:236.

106. Viereck J, Thum T. Circulating noncoding RNAs as biomarkers of cardiovascular disease and injury. Circ Res. 2017;120:381-99.

107. Li, C.; Fang, Z.; Jiang, T.; Zhang, Q.; Liu, C.; Zhang, C.; Xiang, Y. Serum microRNAs Profile from Genome-Wide Serves as a Fingerprint for Diagnosis of Acute Myocardial Infarction and Angina Pectoris. BMC Med. Genomics 2013, 6, 16-8794-6-16.

108. Zeller T, Keller T, Ojeda F, Reichlin T, Twerenbold R, Tzikas S, Wild PS, Reiter M, Czyz E, Lackner KJ, et al. Assessment of microRNAs in patients with unstable Angina Pectoris. Eur Heart J. 2014;35:2106-14.

109. Voellenkle C, van Rooij J, Cappuzzello C, Greco S, Arcelli D, Di Vito L, Melillo G, Rigolini R, Costa E, Crea F, et al. MicroRNA signatures in peripheral blood mononuclear cells of chronic heart failure patients. Physiol Genomics. 2010;42:420-6.
110. Zampetaki A, Willeit P, Tilling L, Drozdov I, Prokopi M, Renard JM, Mayr A, Weger S, Schett G, Shah A, et al. Prospective study on circulating MicroRNAs and risk of myocardial infarction. J Am Coll Cardiol. 2012;60:290-9.

111. D'Alessandra Y, Devanna P, Limana F, Straino S, Di Carlo A, Brambilla PG, Rubino M, Carena MC, Spazzafumo L, De Simone M, et al. Circulating microRNAs are new and sensitive biomarkers of myocardial infarction. Eur Heart J. 2010:31:2765-73.

112. Wang, F.; Long, G.; Zhao, C.; Li, H.; Chaugai, S.; Wang, Y.; Chen, C.; Wang, D.W. Plasma microRNA-133a is a New Marker for both Acute Myocardial Infarction and Underlying Coronary Artery Stenosis. J. Transl. Med. 2013, 11, 222-5876-11-222.

113. Corsten MF, Dennert R, Jochems $S$, Kuznetsova T, Devaux $Y$, Hofstra $L$, Wagner DR, Staessen JA, Heymans S, Schroen B. Circulating MicroRNA208b and MicroRNA-499 reflect myocardial damage in cardiovascular disease. Circ Cardiovasc Genet. 2010;3:499-506.

114. Zhang, Z.; Gao, W.; Long, Q.Q.; Zhang, J.; Li, Y.F.; Liu, D.C.; Yan, J..; Yang, Z.J.; Wang, L.S. Increased Plasma Levels of InCRNA H19 and LIPCAR are Associated with Increased Risk of Coronary Artery Disease in a Chinese Population. Sci. Rep. 2017, 7, 7491-017-07611-z.

115. Kumarswamy R, Bauters C, Volkmann I, Maury F, Fetisch J, Holzmann A, Lemesle G, de Groote P, Pinet F, Thum T. Circulating Long Noncoding RNA, LIPCAR, Predicts Survival in Patients with Heart Failure. Circ Res. 2014;114:1569-75.

116. Vausort M, Wagner DR, Devaux Y. Long Noncoding RNAs in Patients with Acute Myocardial Infarction. Circ Res. 2014;115:668-77.

117. de Gonzalo-Calvo D, Kenneweg F, Bang C, Toro R, van der Meer RW, Rijzewijk LJ, Smit JW, Lamb HJ, Llorente-Cortes V, Thum T. Circulating Long-Non Coding RNAs as Biomarkers of Left Ventricular Diastolic Function and Remodelling in Patients with Well-Controlled Type 2 Diabetes. Sci Rep. 2016;6:37354.

118. Xuan L, Sun L, Zhang Y, Huang Y, Hou Y, Li Q, Guo Y, Feng B, Cui L, Wang $X$, et al. Circulating long non-coding RNAs NRON and MHRT as novel predictive biomarkers of heart failure. J Cell Mol Med. 2017;21:1803-14.

119. Salgado-Somoza A, Zhang L, Vausort M, Devaux Y. The circular RNA MICRA for risk stratification after myocardial infarction. Int J Cardiol Heart Vasc. 2017:17:33-6.

120. Zhao Z, Li X, Gao C, Jian D, Hao P, Rao L, Li M. Peripheral blood circular RNA hsa_circ 0124644 can be used as a diagnostic biomarker of coronary artery disease. Sci Rep. 2017;7:39918.

121. Zhang Z, Yang T, Xiao J. Circular RNAs: promising Biomarkers for Human Diseases. EBioMedicine. 2018;34:267-74.

122. Xiong Y, Liu Y, Cao L, Wang D, Guo M, Jiang A, Guo D, Hu W, Yang J, Tang $Z$, et al. Transcriptomic characteristics of bronchoalveolar lavage fluid and peripheral blood mononuclear cells in COVID-19 Patients. Emerg Microbes Infect. 2020;9:761-70.

123. Ouyang Y, Yin J, Wang W, Shi H, Shi Y, Xu B, Qiao L, Feng Y, Pang L, Wei $F$, et al. Down-regulated gene expression spectrum and immune responses changed during the disease progression in COVID-19 patients. Dis: Clin Infect; 2020.

124. Wen, W.; Su, W.; Tang, H.; Le, W.; Zhang, X.; Zheng, Y.; Liu, X.; Xie, L.; Li, J.; $Y e$, J. et al. Immune Cell Profiling of COVID-19 Patients in the Recovery Stage by Single-Cell Sequencing. Cell. Discov. 2020, 6, 31-020-0168-9. eCollection 2020.

125. Wilk AJ, Rustagi A, Zhao NQ, Roque J, Martínez-Colón GJ, McKechnie $J \mathrm{~L}$, Ivison GT, Ranganath T, Vergara R, Hollis T, et al. A Single-Cell Atlas of the Peripheral Immune Response in Patients with Severe COVID-19. Nat Med. 2020:26:1070-6.

126. Guo, C.; Li, B.; Ma, H.; Wang, X.; Cai, P.; Yu, Q.; Zhu, L.; Jin, L.; Jiang, C.; Fang, J. et al. Single-Cell Analysis of Two Severe COVID-19 Patients Reveals a Monocyte-Associated and Tocilizumab-Responding Cytokine Storm. Nat. Commun. 2020, 11, 3924-020-17834-w.

127. Arunachalam, P.S.; Wimmers, F.; Mok, C.K.P.; Perera, R.A.P.M.; Scott, M.; Hagan, T.; Sigal, N.; Feng, Y.; Bristow, L.; Tak-Yin Tsang, O. et al. Systems Biological Assessment of Immunity to Mild Versus Severe COVID-19 Infection in Humans. Science 2020, 369, 1210-1220.

128. Schulte-Schrepping J, Reusch N, Paclik D, Baßler K, Schlickeiser S, Zhang B, Krämer B, Krammer T, Brumhard S, Bonaguro L, et al. Severe COVID-19 is marked by a dysregulated myeloid cell compartment. Cell. 2020;182(1419-1440):e23.

129. Lee, J.S.; Park, S.; Jeong, H.W.; Ahn, J.Y.; Choi, S.J.; Lee, H.; Choi, B.; Nam, S.K.; Sa, M.; Kwon, J.S. et al. Immunophenotyping of COVID-19 and 
Influenza Highlights the Role of Type I Interferons in Development of Severe COVID-19. Sci. Immunol. 2020, 5, eabd1554. https://doi. org/10.1126/sciimmunol.abd1554.

130. Zhang JY, Wang XM, Xing X, Xu Z, Zhang C, Song JW, Fan X, Xia P, Fu JL, Wang SY, et al. Single-cell landscape of immunological responses in patients with COVID-19. Nat Immunol. 2020;21:1107-18.

131. Sharma A, Garcia G. Human iPSC-Derived Cardiomyocytes are Susceptible to SARS-CoV-2 Infection. Cell Rep Med. 2020;1:100052.

132. Bojkova, D.; Wagner, J.U.G.; Shumliakivska, M.; Aslan, G.S.; Saleem, U. Hansen, A.; Luxán, G.; Günther, S.; Pham, M.D.; Krishnan, J. et al. SARSCoV-2 Infects and Induces Cytotoxic Effects in Human Cardiomyocytes. Cardiovasc. Res. 2020.

133. Pérez-Bermejo, J.A.; Kang, S.; Rockwood, S.J.; Simoneau, C.R.; Joy, D.A.; Ramadoss, G.N.; Silva, A.C.; Flanigan, W.R.i Li, H.; Nakamura, K. et al. SARS-CoV-2 Infection of Human iPSC-Derived Cardiac Cells Predicts Novel Cytopathic Features in Hearts of COVID-19 Patients. bioRxiv 2020

134. Blanco-Melo D, Nilsson-Payant BE, Liu WC, Uhl S, Hoagland D, Moller R, Jordan TX, Oishi K, Panis M, Sachs D, et al. Imbalanced Host Response to SARS-CoV-2 Drives Development of COVID-19. Cell. 2020;181(1036-1045):e9.

135. Gardinassi LG, Souza COS, Sales-Campos H, Fonseca SG. Immune and metabolic signatures of COVID-19 revealed by transcriptomics data reuse. Front Immunol. 2020;11:1636.

136. Leite, G.G.F.; Scicluna, B.P.; van der Poll, T.; Salomão, R. Genetic Signature Related to Heme-Hemoglobin Metabolism Pathway in Sepsis Secondary to Pneumonia. NPJ Syst. Biol. Appl. 2019, 5, 26-019-0105-4. eCollection 2019

137. Figueiredo RT, Fernandez PL, Mourao-Sa DS, Porto BN, Dutra FF, Alves LS, Oliveira MF, Oliveira PL, Graça-Souza AV, Bozza MT. Characterization of heme as activator of toll-like receptor 4. J Biol Chem. 2007:282:20221-9.

138. Sparkenbaugh EM, Chantrathammachart P, Wang S, Jonas W, Kirchhofer D, Gailani D, Gruber A, Kasthuri R, Key NS, Mackman N, et al. Excess of heme induces tissue factor-dependent activation of coagulation in mice. Haematologica. 2015;100:308-14.

139. FitzGerald E.S. and Jamieson A.M. Unique Transcriptional Changes in Coagulation Cascade Genes in SARS-CoV-2-Infected Lung Epithelial Cells: A Potential Factor in COVID-19 Coagulopathies. medRxiv: the preprint server for health sciences 2020

140. Desai, N.; Neyaz, A.; Szabolcs, A.; Shih, A.R.; Chen, J.H.; Thapar, V.; Nieman, L.T.: Solovyov, A.; Mehta, A.: Lieb, D.J. et al. Temporal and Spatial Heterogeneity of Host Response to SARS-CoV-2 Pulmonary Infection. medRxiv 2020

141. Shirazi, L.F.; Bissett, J.; Romeo, F.; Mehta, J.L. Role of Inflammation in Heart Failure. Curr. Atheroscler. Rep. 2017, 19, 27-017-0660-3.

142. Levick SP, Goldspink PH. Could interferon-gamma be a therapeutic target for treating heart failure? Heart Fail Rev. 2014;19:227-36.

143. Swirski FK, Nahrendorf M. Cardioimmunology: the Immune System in Cardiac Homeostasis and Disease. Nat Rev Immunol. 2018;18:733-44.

144. Devaux B, Scholz D, Hirche A, Klovekorn WP, Schaper J. Upregulation of Cell Adhesion Molecules and the Presence of Low Grade Inflammation in Human Chronic Heart Failure. Eur Heart J. 1997:18:470-9.

145. Lu D, Chatterjee S, Xiao K, Riedel I, Wang Y, Foo R, Bär C, Thum T. MicroRNAs Targeting the SARS-CoV-2 Entry Receptor ACE2 in Cardiomyocytes. J Mol Cell Cardiol. 2020;148:46-9.

146. Magenta A, Cencioni C, Fasanaro P, Zaccagnini G, Greco S, Sarra-Ferraris G, Antonini A, Martelli F, Capogrossi MC. miR-200c is Upregulated by Oxidative Stress and Induces Endothelial Cell Apoptosis and Senescence Via ZEB1 Inhibition. Cell Death Differ. 2011:18:1628-39.

147. Liu Z.; Wang J.; Xu Y.; Guo M.; Mi K.; Xu R.; Pei Y.; Zhang Q.; Luan X.; Hu Z. et al. Implications of the Virus-Encoded miRNA and Host miRNA in the Pathogenicity of SARS-CoV-2. arXiv:2004. 04874 [q-bio. GN] 2020.

148. Arisan ED, Dart A, Grant GH, Arisan S, Cuhadaroglu S, Lange S, Uysal-Onganer P. The Prediction of miRNAs in SARS-CoV-2 Genomes: hsa-miR Databases Identify 7 Key miRs Linked to Host Responses and Virus Pathogenicity-Related KEGG Pathways Significant for Comorbidities. Viruses. 2020:12:614. https://doi.org/10.3390/v12060614.

149. Khan, M.A.; Sany, M.R.U.; Islam, M.S.; Islam, A.B.M.M.K. Epigenetic Regulator miRNA Pattern Differences among SARS-CoV, SARS-CoV-2, and SARS-CoV-2 World-Wide Isolates Delineated the Mystery Behind the Epic Pathogenicity and Distinct Clinical Characteristics of Pandemic COVID-19. Front. Genet. 2020, 11, 765.

150. Chauhan, N.; Jaggi, M.; Chauhan, S.C.; Yallapu, M.M. COVID-19: Fighting the Invisible Enemy with microRNAs. Expert Rev. Anti Infect. Ther. 2020, 1-9.

151. Vishnubalaji R, Shaath H, Alajez NM. Protein Coding and Long Noncoding RNA (IncRNA) Transcriptional Landscape in SARS-CoV-2 Infected Bronchial Epithelial Cells Highlight a Role for Interferon and Inflammatory Response. Genes. 2020;11:760. https://doi.org/10.3390/ genes 11070760.

152. Turjya R.R.; Khan A.; Islam A.B.M.M.K. Perversely Expressed Long Noncoding RNAs can Alter Host Response and Viral Proliferation in SARS-CoV-2 Infection. bioRxiv.

153. Li, C.; Hu, X.; Li, L.; Li, J.H. Differential microRNA Expression in the Peripheral Blood from Human Patients with COVID-19. J. Clin. Lab. Anal. 2020, e23590.

154. Josset L, Tchitchek N, Gralinski LE, Ferris MT, Eisfeld AJ, Green RR, Thomas MJ, Tisoncik-Go J, Schroth GP, Kawaoka Y, et al. Annotation of Long Non-Coding RNAs Expressed in Collaborative Cross Founder Mice in Response to Respiratory Virus Infection Reveals a New Class of Interferon-Stimulated Transcripts. RNA Biol. 2014;11:875-90.

155. Qian S, Ding JY, Xie R, An JH, Ao XJ, Zhao ZG, Sun JG, Duan YZ, Chen ZT, Zhu B. MicroRNA Expression Profile of Bronchioalveolar Stem Cells from Mouse Lung. Biochem Biophys Res Commun. 2008;377:668-73.

156. Peng, X.; Gralinski, L.; Ferris, M.T.; Frieman, M.B.; Thomas, M.J.; Proll, S.; Korth, M.J.; Tisoncik, J.R.; Heise, M.; Luo, S. et al. Integrative Deep Sequencing of the Mouse Lung Transcriptome Reveals Differential Expression of Diverse Classes of Small RNAs in Response to Respiratory Virus Infection. mBio 2011, 2, https://doi.org/10.1128/ mbio.00198-11. Print 2011.

157. Peng, X.; Gralinski, L.; Armour, C.D.; Ferris, M.T.; Thomas, M.J.; Proll, S Bradel-Tretheway, B.G.; Korth, M.J.; Castle, J.C.; Biery, M.C. et al. Unique Signatures of Long Noncoding RNA Expression in Response to Virus Infection and Altered Innate Immune Signaling. mBio 2010, 1, https ://doi.org/10.1128/mbio.00206-10.

158. O'Connell RM, Kahn D, Gibson WS, Round JL, Scholz RL, Chaudhuri AA, Kahn ME, Rao DS, Baltimore D. MicroRNA-155 Promotes Autoimmune Inflammation by Enhancing Inflammatory T Cell Development. Immunity. 2010;33:607-19.

159. Testa, U.; Pelosi, E.; Castelli, G.; Labbaye, C. miR-146 and miR-155: Two Key Modulators of Immune Response and Tumor Development. Noncoding RNA 2017, 3, https://doi.org/10.3390/ncrna3030022.

160. da Costa Martins PA, Bourajjaj M, Gladka M, Kortland M, van Oort RJ, Pinto YM, Molkentin JD, De Windt LJ. Conditional dicer gene deletion in the postnatal myocardium provokes spontaneous cardiac remodeling. Circulation. 2008;118:1567-76.

161. Thum T, Gross C, Fiedler J, Fischer T, Kissler S, Bussen M, Galuppo P, Just S, Rottbauer W, Frantz S, et al. MicroRNA-21 Contributes to Myocardial Disease by Stimulating MAP Kinase Signalling in Fibroblasts. Nature. 2008;456:980-4.

162. Mann, M.; Mehta, A.; Zhao, J.L.; Lee, K.: Marinov, G.K.: Garcia-Flores, Y. Lu, L.F.; Rudensky, A.Y.; Baltimore, D. Author Correction: An NF-kappaB-microRNA Regulatory Network Tunes Macrophage Inflammatory Responses. Nat. Commun. 2018, 9, 3338-018-05720-5.

163. Das A, Ganesh K, Khanna S, Sen CK, Roy S. Engulfment of Apoptotic Cells by Macrophages: a Role of microRNA-21 in the Resolution of Wound Inflammation. J. Immunol. 2014;192:1120-9.

164. Ma X, Becker Buscaglia LE, Barker JR, Li Y. MicroRNAs in NF-kappaB Signaling. J Mol Cell Biol. 2011;3:159-66.

165. Vegter EL, Ovchinnikova ES, van Veldhuisen DJ, Jaarsma T, Berezikov E, van der Meer P, Voors AA. Low Circulating microRNA Levels in Heart Failure Patients are Associated with Atherosclerotic Disease and Cardiovascular-Related Rehospitalizations. Clin Res Cardiol. 2017:106:598-609

166. Lu H, Buchan RJ, Cook SA. MicroRNA-223 Regulates Glut4 Expression and Cardiomyocyte Glucose Metabolism. Cardiovasc Res. 2010;86:410-20.

167. Gangwar RS, Rajagopalan S, Natarajan R, Deiuliis JA. Noncoding RNAs in Cardiovascular Disease: pathological Relevance and Emerging Role as Biomarkers and Therapeutics. Am J Hypertens. 2018;31:150-65. 
168. Ahmed ASI, Dong K, Liu J, Wen T, Yu L, Xu F, Kang X, Osman I, Hu G, Bunting KM, et al. Long Noncoding RNA NEAT1 (Nuclear Paraspeckle Assembly Transcript 1) is Critical for Phenotypic Switching of Vascular Smooth Muscle Cells. Proc Natl Acad Sci U S A. 2018;115:E8660-7.

169. Zhang, P.; Cao, L.; Zhou, R.; Yang, X.; Wu, M. The IncRNA Neat1 Promotes Activation of Inflammasomes in Macrophages. Nat. Commun. 2019, 10, 1495-019-09482-6.

170. Carrara M, Fuschi P, Ivan C, Martelli F. Circular RNAs: methodological Challenges and Perspectives in Cardiovascular Diseases. J Cell Mol Med. 2018;22:5176-87.
171. Emanueli C, Badimon L, Martelli F, Potočnjak I, Carpusca I, Robinson EL, Devaux Y. Call to Action for the Cardiovascular Side of COVID-19. Eur Heart J. 2020;41:1796-7.

\section{Publisher's Note}

Springer Nature remains neutral with regard to jurisdictional claims in published maps and institutional affiliations.
Ready to submit your research? Choose BMC and benefit from:

- fast, convenient online submission

- thorough peer review by experienced researchers in your field

- rapid publication on acceptance

- support for research data, including large and complex data types

- gold Open Access which fosters wider collaboration and increased citations

- maximum visibility for your research: over $100 \mathrm{M}$ website views per year

At BMC, research is always in progress.

Learn more biomedcentral.com/submissions 